Prepared for the U.S. Department of Energy under Contract DE-AC05-76RL01830

\title{
Technology Review of
}

Nondestructive Methods for

Examination of Water Intrusion

Areas on Hanford's Double-

\section{Shell Waste Tanks}

ML Watkins

AF Pardini

April 2008 


\title{
DISCLAIMER
}

This report was prepared as an account of work sponsored by an agency of the United States Government. Neither the United States Government nor any agency thereof, nor Battelle Memorial Institute, nor any of their employees, makes any warranty, express or implied, or assumes any legal liability or responsibility for the accuracy, completeness, or usefulness of any information, apparatus, product, or process diselosed, or represents that its use would not infringe privately owned rights. Reference herein to any specific commercial product, process, or service by trade name, trademark, manufacturer, or otherwise does not necessarily constitute or imply its endorsement, recommendation, or favoring by the United States Government or any agency thereof, or Battelle Memorial Institute. The views and opinions of authors expressed herein do not necessarily state or reflect those of the United States Government or any agency thereof.

\author{
PACIFIC NORTHWEST NATIONAL LABORATORY \\ operated by \\ BATTELLE \\ for the \\ UNTTED STATES DEPARTMENT OF ENERGY \\ under Contract DE-AC05-76RL01830 \\ Printed in the United States of America \\ Available to DOE and DOE contractors from the \\ Office of Scientific and Technical Information, \\ P.O. Box 62, Oak Ridge, TN 37831-0062; \\ ph: (865) 576-8401 \\ fax: (865) $576-5728$ \\ email: reports@adonis.osti.gov \\ Available to the public from the National Technical Information Service, \\ U.S. Department of Commerce, 5285 Port Royal Rd., Springfield, VA 22161 \\ ph: (800) 553-6847 \\ fax: (703) 605-6900 \\ email: orders@ntis.fedworld.gov \\ online ordering: http://www.ntis.gov/ordering.htm
}

This document was printed on recycled paper.

(9/2003) 
PNNL-17522

RPP-ASMT-37898

\section{Technology Review of Nondestructive Methods for Examination of Water Intrusion Areas on Hanford's Double-Shell Waste Tanks}

M. L. Watkins

A. F. Pardini

April 2008

Prepared for

the U.S. Department of Energy

under Contract DE-AC05-76RL01830

Pacific Northwest National Laboratory

Richland, Washington 99352 



\section{Summary and Key Outcomes}

\section{Objective}

Under a contract with CH2M Hill Hanford Group, Inc. (CH2M HILL), Pacific Northwest National Laboratory (PNNL) has performed a review of the nondestructive evaluation (NDE) technology and methods for examination of the concrete dome structure of Hanford's double-shell tanks (DSTs). The objective was to provide a matrix of methodologies that could be evaluated based on applicability, ease of deployment, and results that could provide information that could be used in the ongoing structural analysis of the tank dome.

PNNL performed a technology evaluation with the objective of providing a critical literature review for all applicable technologies based on constraints provided by CH2M HILL. These constraints were not mandatory, but were desired. These constraints included performing the evaluation without removing any soil from the top of the tank, or if necessary, requesting that the hole diameter needed to gain access to evaluate the top of the tank structure to be no greater than approximately 12-in. in diameter. PNNL did not address the details of statistical sampling requirements as they depend on an unspecified risk tolerance. PNNL considered these during the technology evaluation and have reported the results in the remainder of this document.

\section{Key Outcomes}

Many of the basic approaches to concrete inspection that were reviewed in previous efforts (e.g., 2002 Workshop on NDE of Concrete) are still in use. These include electromagnetic, acoustic, radiographic, etc. The primary improvements in these tools have focused on providing quantitative image reconstruction, thus providing inspectors and analysts with three-dimensional data sets that allow for operator visualization of relevant abnormalities and analytical integration into structural performance models (e.g., finite element simulations). Available instruments, such as radar used for bridge deck inspections, rely on post-processing algorithms and do not provide real-time visualization. Commercially available equipment only provides qualitative indications of relative concrete damage. It cannot be used as direct input for structural analysis to assess fitness for use and if necessary to de-rate critical components. There are currently no tools that automatically convert the NDE data to formats compatible with structural analysis programs. While radiographic techniques still provide significant advantages in spatial resolution, non-ionizing techniques are still preferred. Radar imagining in the 1-5 GHz has become the most useful. Unfortunately the algorithms and underlying assumptions used in these reconstructions are proprietary, and it is not possible to assess the quality and limitations of the analytical methods used to generate the derived structural data.

The hypothesis that water intrusion may contribute to potential rebar corrosion of the tank domes provided the primary guidance in reviewing and evaluating available NDE technologies. Of primary concern is the need to employ technologies that provide the best opportunity for visualizing the rebar and providing quantitative data that can be integrated into structural analysis efforts to better understand and quantify the structural capacity of the domes. 
Several techniques (e.g., electrochemical) may ultimately provide useful and corroborative information. The decision to make such measurements should probably be made based on the outcome of visual and internal imaging inspections. In addition, these and other commercially available techniques (e.g., impulse response) that either provide spot measurements or are qualitative and rely heavily on "asfabricated" baseline data as a reference (it is PNNL's understanding such data is not available) were not recommended.

The conclusion is that an imaging system capable of locating and quantifying the distribution and conditions of the cement, aggregate, and rebar will provide the most valuable baseline upon which to build a case for the integrity of the structure. If successful, such a system would fulfill the need to incorporate valuable data into current structural load capacity analysis.

In the short term, it is recommended that appropriate structural mock-ups be fabricated. These mockups should be specified based on the existing construction drawings and photographic evidence of the construction joint area of the tank dome. Data collected from the mock-up will allow for an assessment of the dependence of measurement capability on access hole size. In considering the relative cost, technical maturity, and fundamental sensitivity to the degradation mechanisms of water intrusion and corrosion, PNNL recommends prioritizing the quantitative evaluation and development of an inspection system based on radar imaging technology. Assuming water intrusion is worst at the top layer of rebar, radar should be sensitive at this depth and may be sensitive to concrete cracks with intrusion of water. It may also be feasible and economically reasonable to evaluate thermographic and radiographic techniques using the mock-ups. A methodology to convert radar data file formats to be compatible with structural analysis programs should be pursued to assess the implications of any findings. 
RPP-ASMT-37898

\section{Contents}

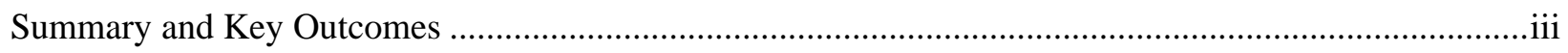

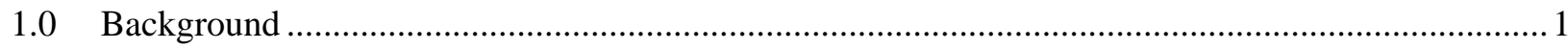

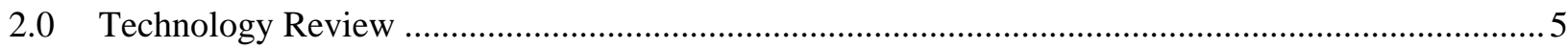

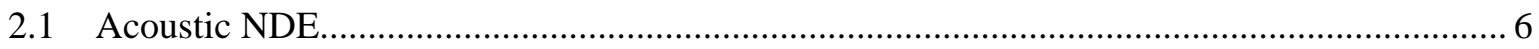

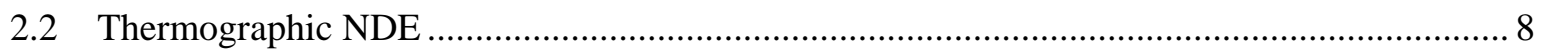

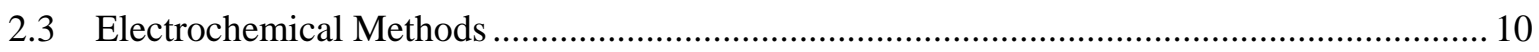

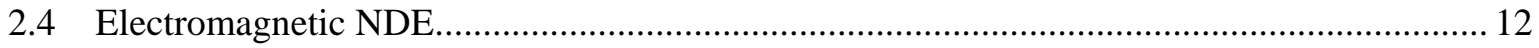

3.0 Description of Relevant Material and Physical Properties........................................................... 17

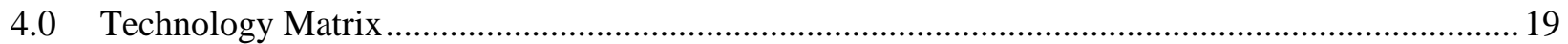

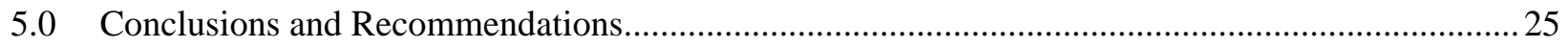

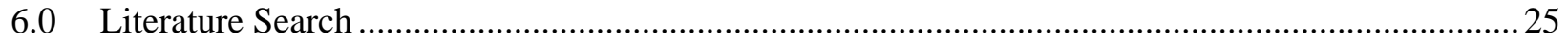

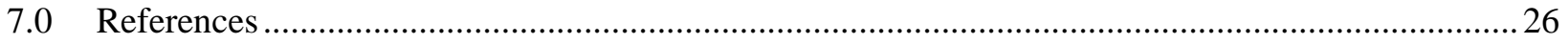


RPP-ASMT-37898

\section{Figures}

1. Mineral Build-up in Converging Area of Primary and Secondary Upper Portion of Tank ................. 1

2. Interface between the Primary and Secondary Tank .............................................................. 2

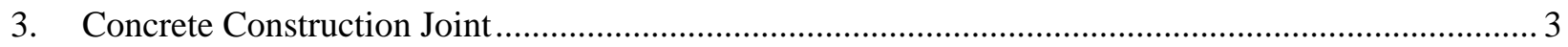

4. Portion of the Tank Dome Showing Possible Leak Paths ............................................................... 3

5. Upper Haunch and Concrete Construction Joint......................................................................... 4

6. Example of Concrete Construction of the Tank Dome Showing the Location of the

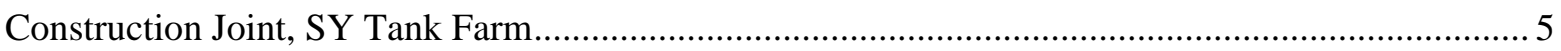

7. Broad Acoustic Frequency Bands Associated with Stress Wave Propagation ................................... 6

8. Commercial Impact-Echo Instrumentation .............................................................................. 7

9. Example of Ultrasonic Pitch-Catch Inspection System Applied in the Single-Sided Mode................. 7

10. Example of Thermal NDE System for the Inspection of Tank Wall and Boiler Section..................... 9

11. Thermographic Inspection of a Concrete Wall Using Diurnal Cycle to Detect Large Voids .............. 10

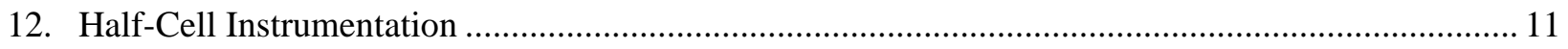

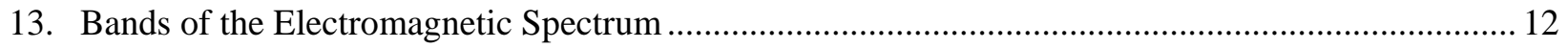

14. Images of Reinforced Concrete of Different Thickness.............................................................. 13

15. Handheld Radar System from Sensors \& Software Inc. and 3D Rendering of Radar Data................ 15

16. Portable Radar System from Geophysical Survey Systems, Inc.................................................. 15

17. Time-Domain Representation of Radar Reflections from Rebar .................................................... 16

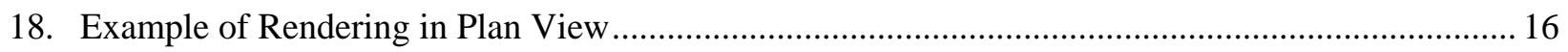

19. Illustration of the Dimensional Aperture Presented to the Inspection Technology ........................... 18 


\subsection{Background}

The AY tank farm was constructed in the Hanford 200 East Area between 1968 and 1970. The farm contains two double-shell tanks (DSTs), 241-AY-101 (AY-101) and 241-AY-102 (AY-102), each with a capacity of 1,000,000 gallons. The tanks were designed to store highly radioactive waste from the PUREX plant. AY-101 entered service in April 1971. Video inspections in early 2001 showed corrosion in various locations on the walls of the annulus. The annulus ventilation system had been inoperable for roughly 10 years leading to a hypothesis that the corrosion was the result of water intrusion into the annulus areas without ventilation to remove it. After examinations, AY-101 was deemed fit for use in 2003 (RPP-13361 ${ }^{(\mathrm{a})}$ ), which was independently reviewed (Stewart et al. 2003). The annulus of AY-101 showed signs of water intrusion and additional rust and mineral deposits during UT inspections performed in 2006. This report does not address the source of the water but concentrates on the possible paths. Figure 1 provides photos taken of the upper portion of the primary tank (converging with the secondary tank) in the same location in 2001 and again in 2006 showing additional intrusion with heavy mineral deposits. ${ }^{(\mathrm{b})}$
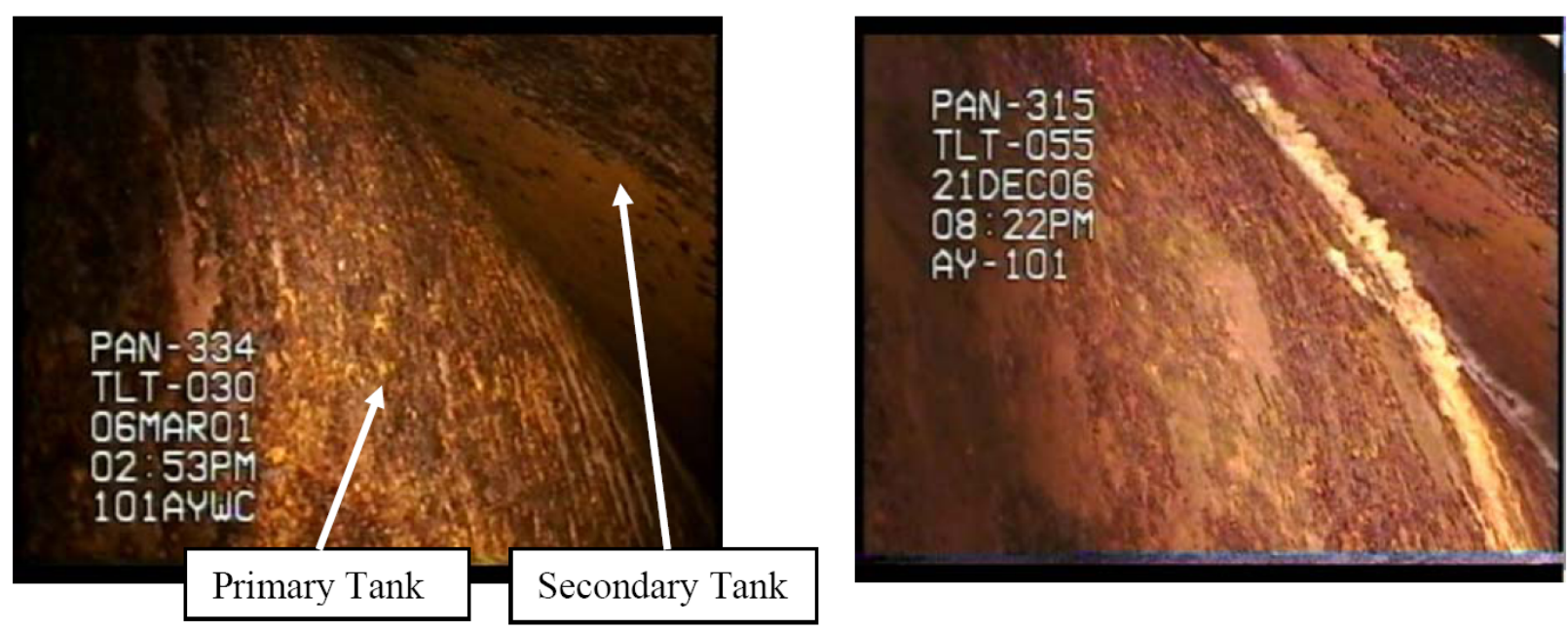

Figure 1. Mineral Build-up in Converging Area of Primary and Secondary Upper Portion of Tank. Left photo taken in 2001, right taken in 2006.

Tank Farm drawings (241-AY) show how a 1/2-in. gap was maintained at the interface between the primary (interior) tank and the secondary tank during construction. This interface may have provided a leak path that channeled water between the secondary and primary tank interface and under a flashing strip that was tack welded over the secondary/primary interface. Any water that was able to migrate

(a) Duncan GP. March 2003. Tank 241-AY-101 Fitness for Service. RPP-13361, Rev. 0. CH2M Hill Hanford Group, Inc., March 2003.

(b) Hagensen AR and LP Djang. May 2007. 241-AY-101/102 Annulus Moisture Intrusion Analysis. RPP-RPT33273, Rev. 0. ARES Corporation for CH2M Hill Hanford Group, Inc., Richland, Washington. Report is attachment to letter dated May 17, 2007 to Mr. D. L. Noyes, U.S. Department of Energy, from Mark S. Spears, CH2M Hill Hanford Group, Inc., Richland, Washington. 
through the concrete could collect and run down the outside of the primary tank into the annulus region. Figure 2 shows the construction of the interface.

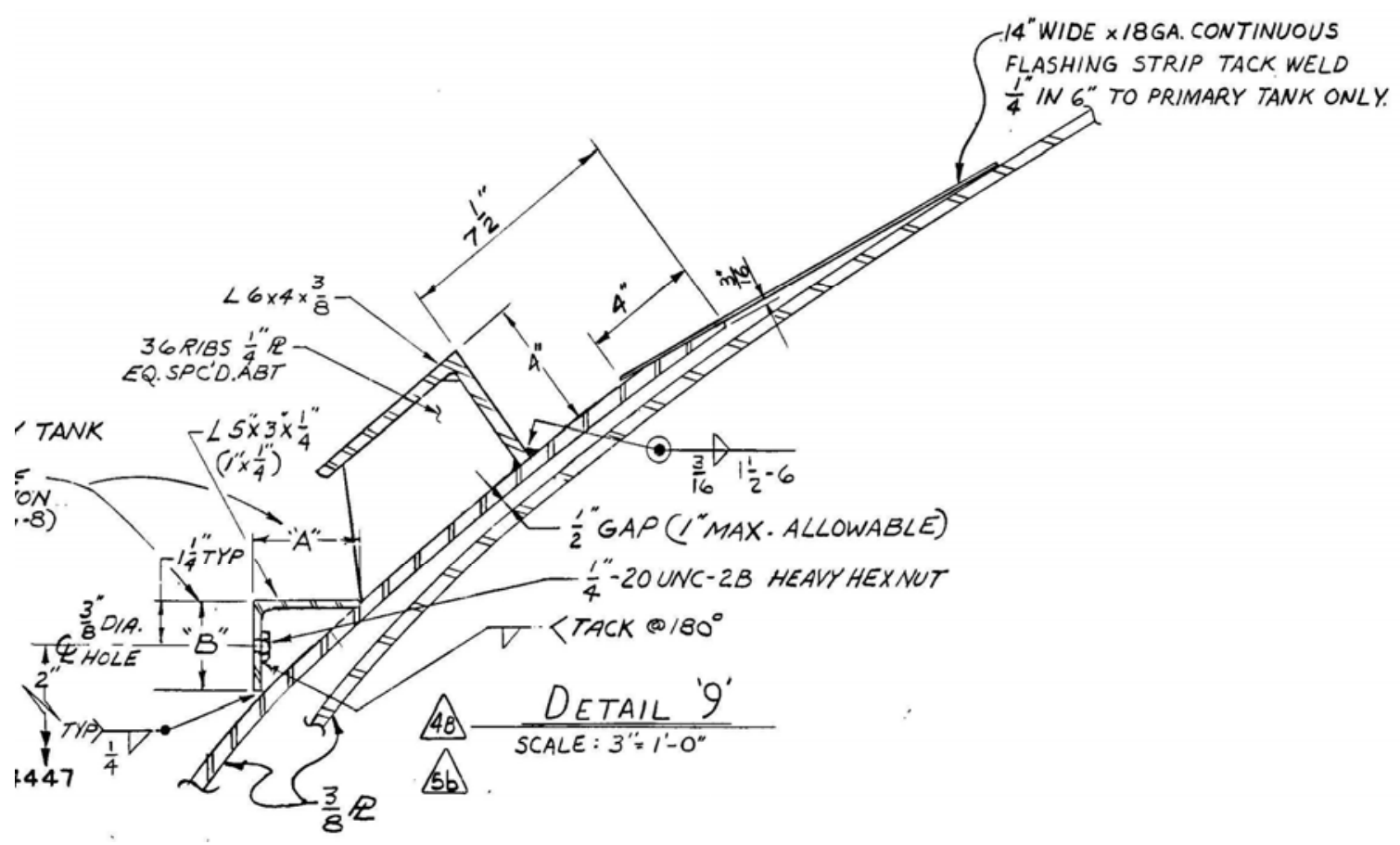

Figure 2. Interface between the Primary and Secondary Tank

Current hypotheses concerning how the water intrusion into the annulus is taking place include leakage through a construction joint located just above the upper haunch area where the primary and secondary tank converge and the interface between risers in the primary tank dome and the surrounding concrete. These possible intrusion areas are shown graphically in Figure 3 and Figure 4, respectively. In this report, higher consideration was given to the intrusion developing from the construction joint instead of the risers. Therefore, techniques were evaluated that would analyze the concrete at the joint instead of attempting to analyze through the riser wall-to-concrete interface. Albeit valuable data may be ascertained using techniques (especially acoustic) that could be acquired by sensing the riser to concrete interface or areas between risers, PNNL made a general (unsubstantiated) assumption that the interface between the riser and surrounding concrete would not provide reliable data with regard to the surrounding rebar. It may however provide an indication of coupling between the riser and concrete indicating a possible leak path. This could further be explored during mock-up construction.

Figure 5 provides the drawing of the construction joint and the location of the rebar. At least two rebar traverse the construction joint equally spaced around the tank. Water intrusion in the area of the construction joint could increase the likelihood of corrosion as water would be in direct contact with the rebar. Corrosion products that build up in this area could cause concrete degradation in the form of spalling. 


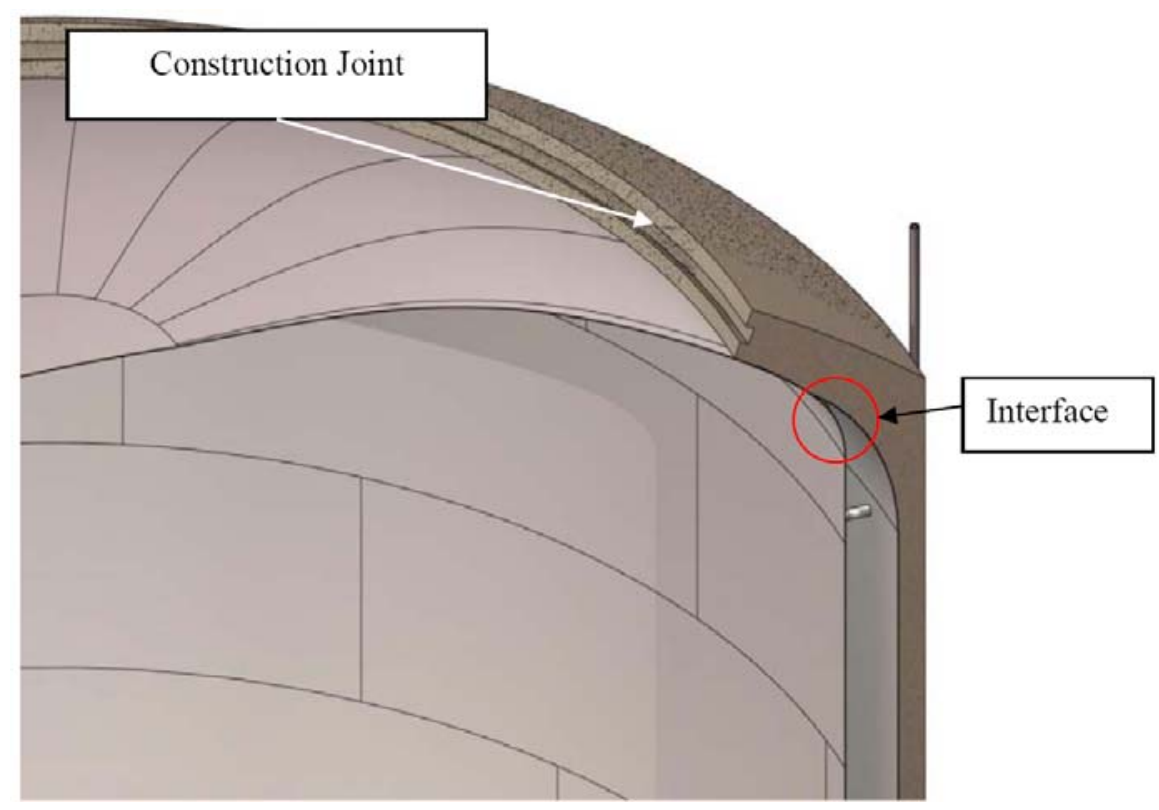

Figure 3. Concrete Construction Joint

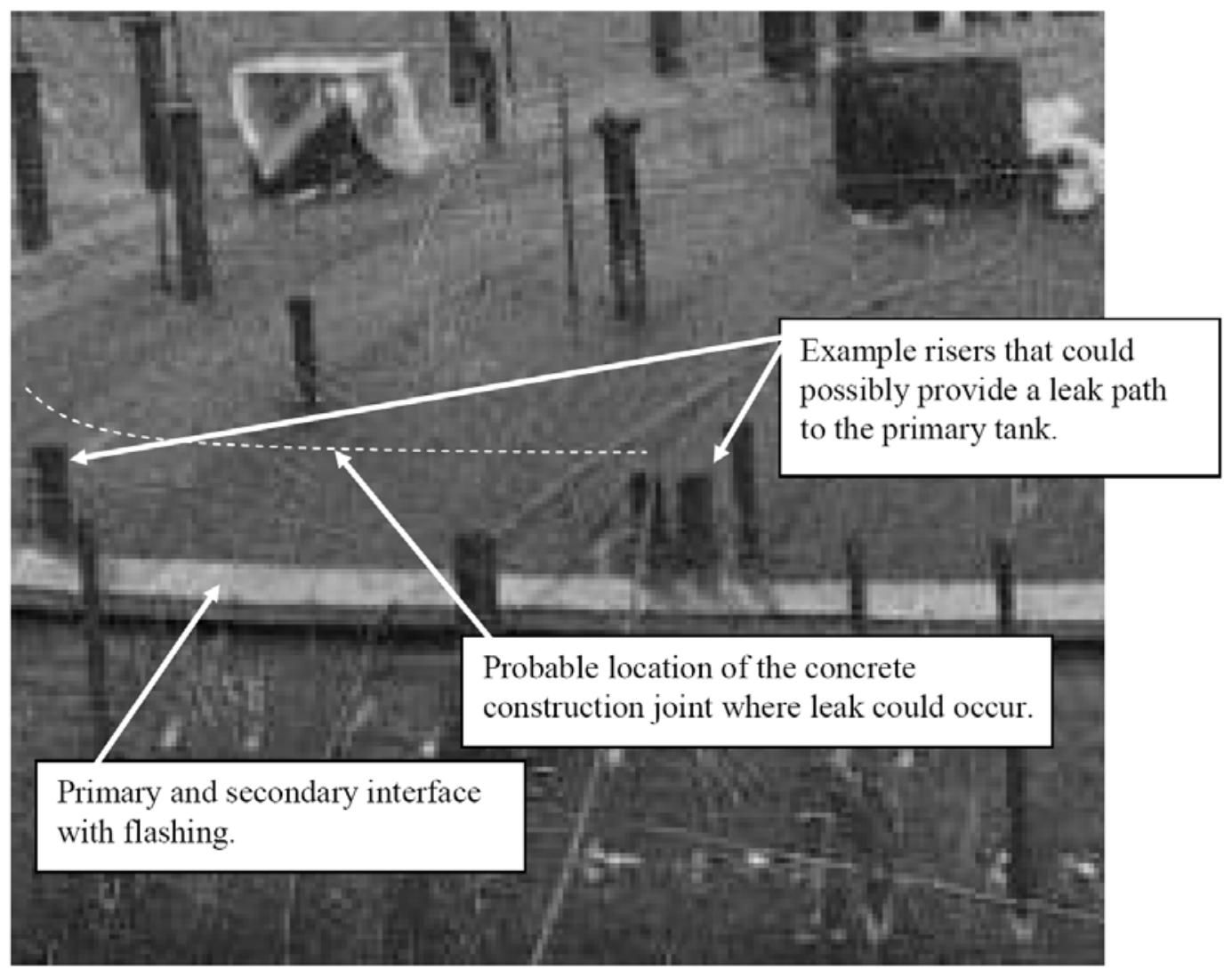

Figure 4. Portion of the Tank Dome (prior to concrete placement) Showing Possible Leak Paths 
An early photograph (Figure 6) shows the method used to place concrete on the tank dome of 241-SY-101 (the same method was used for the AY tanks). This photo shows the radial traversing rebar as not disconnected at the construction joint, but continuing directly through the form used to contain the concrete. Typically when this type of construction joint is used, wood that is used to contain the concrete during placement is removed after the concrete is set using bars and hammers. Any remaining wood that is held by the concrete (seeping around the form, etc.) is removed by sandblasting the wood away and roughing the concrete for the next placement.

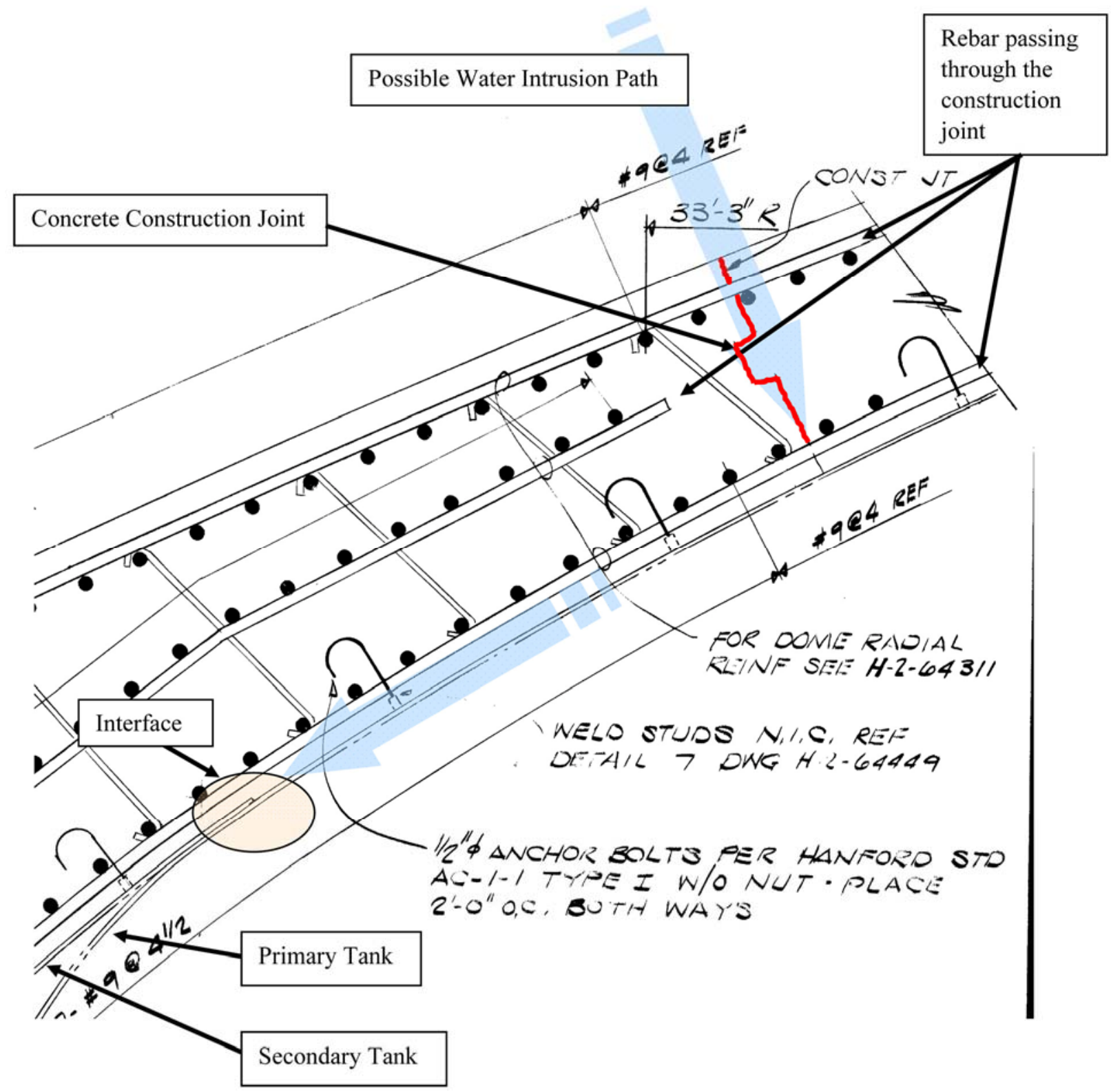

Figure 5. Upper Haunch and Concrete Construction Joint 


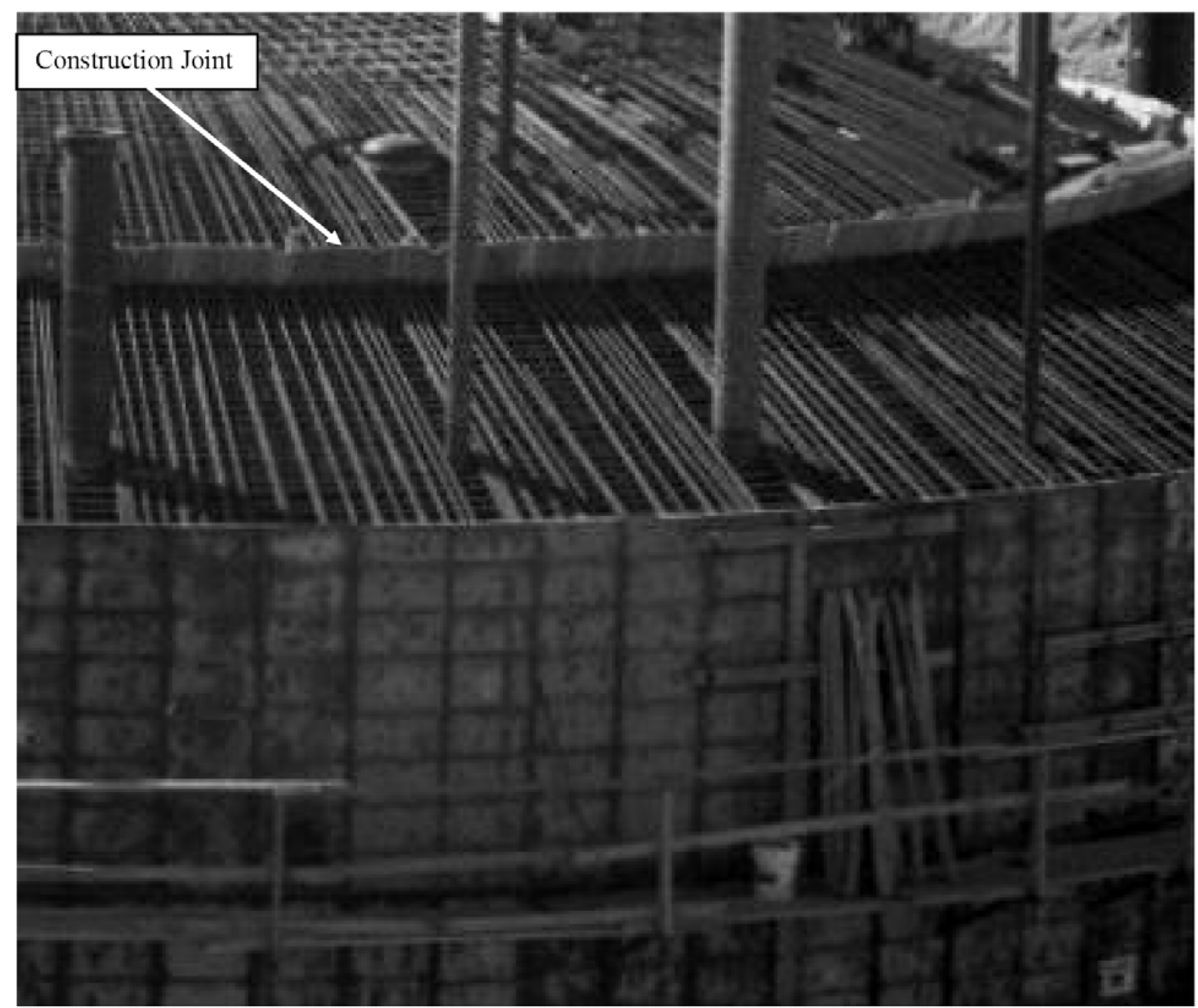

Figure 6. Example of Concrete Construction of the Tank Dome Showing the Location of the Construction Joint, 241-SY Tank Farm

\subsection{Technology Review}

The American Concrete Institute (ACI) Committee (228 - Nondestructive Testing of Concrete) lists in-place strength assessments $(228.1 \mathrm{R})$ and nondestructive test methods for the evaluation of concrete in structures (228.2R) (ACI Committee 228 2003). The former includes both non-invasive and minimally invasive methods that are highly localized, relatively straightforward, and have not matured significantly in the last decade. In light of an initial visual inspection it may prove valuable to consider performing such evaluations. However, it is not likely that these methods would provide direct quantitative information regarding damage associated with the suspected water intrusion described in Section 1. Because descriptions of these invasive methods are readily available, they were not reviewed. The focus in this section will be on nondestructive methods. 
RPP-ASMT-37898

\subsection{Acoustic NDE}

Active acoustic NDE uses stress waves to probe structures. The stress wave methods identified in ACI 228.2R represent a subset of the general class of methods that utilizes acoustic wave propagation. Stress waves can also be described as strain wave propagation within the elastic limits of a material. Generically speaking, stress wave methods involve an elastic excitation and a receiver to monitor the response. Figure 7 illustrates the broad frequency bands for acoustic wave propagation.

Diffraction dictates that the spatial resolution of an acoustic inspection technique is the ratio of the defect to the wavelength (inversely proportional to frequency). Typical signal features of interest are amplitude, frequency content, and time of flight. Deducing the health of the concrete structure requires either a propagation model that allows for the derivation of elastic moduli or defect geometry from the anticipated response or a baseline reference response of "good" material. Sounding is the simplest example, involving an impact source and listening with the human ear for "abnormal" responses such as a shift to lower frequencies and attenuation associated with discontinuities. More advanced methods employ transducer(s) as sources and signal receivers. Figure 8 illustrates commercial impact-echo equipment and Figure 9 illustrates a commercial unit involving a pitch-catch transducer pair. In more sophisticated versions of these methods, frequency analysis is used to assess the presence and depth of concrete flaws.

The interpretation of results obtained using the above techniques rely on at least a rudimentary acoustic propagation model and assumptions that take into account the properties and geometry of the components within the structure. In the current case this would be the cement, aggregate, and rebar. A more common approach is to develop a sampling strategy that compares reference material (i.e., some standard of acceptable concrete) with material at locations suspected of being defective or deficient. Successful utilization of an inspection program based on these techniques hinges on the implementation of a rigorous validation of quantitative acceptance criteria.

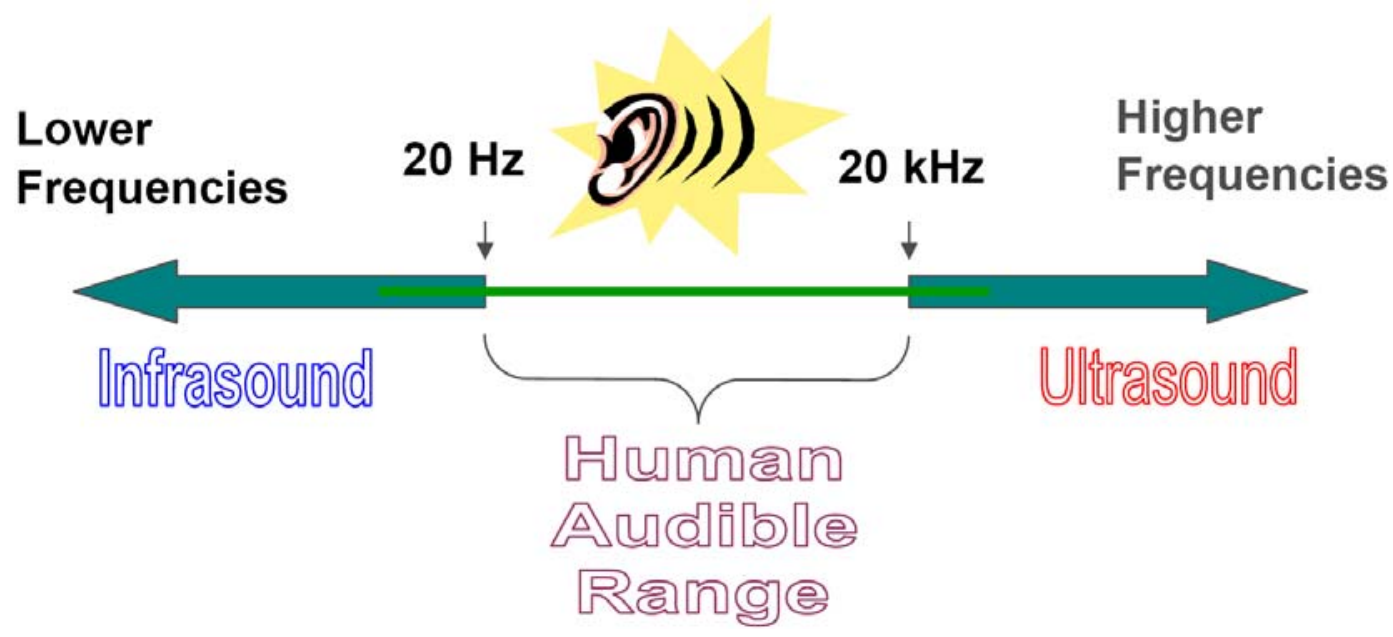

Figure 7. Broad Acoustic Frequency Bands Associated with Stress Wave Propagation 

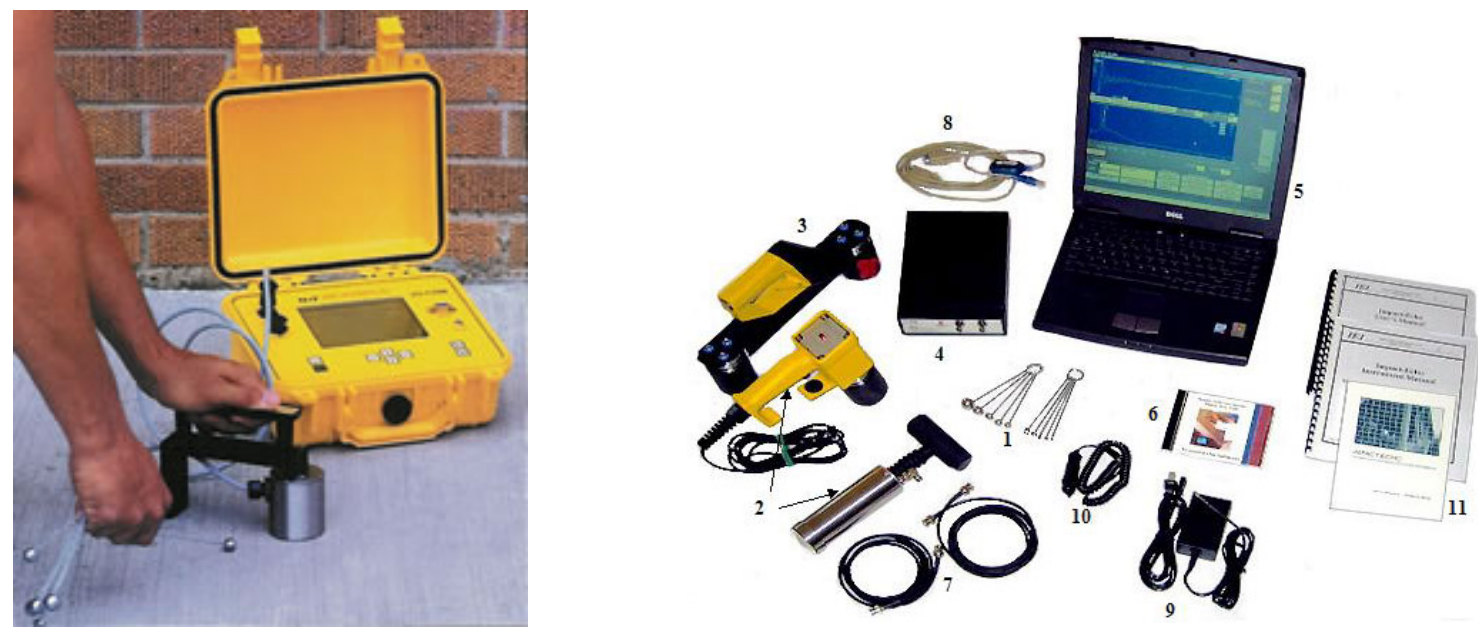

Figure 8. Commercial Impact-Echo Instrumentation. A mechanical impact provides the excitation and an acoustic transducer senses the stress wave response of the concrete. Images courtesy of Impact-Echo Instruments, LLC.

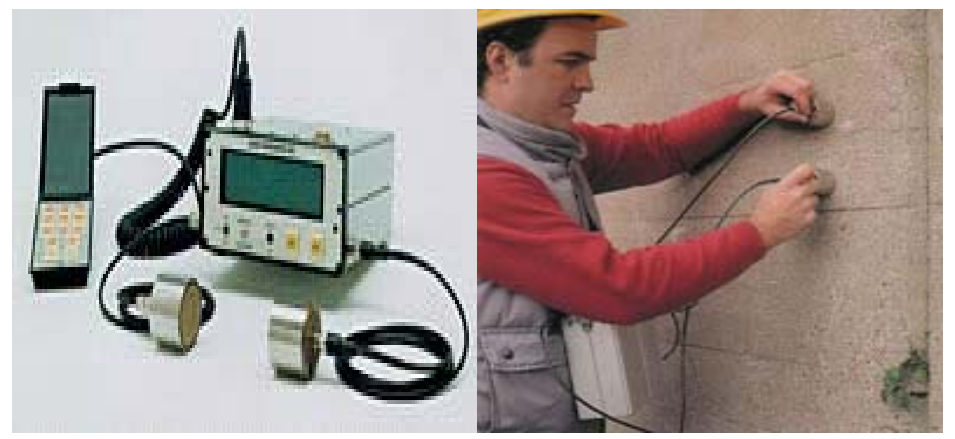

Figure 9. Example of Ultrasonic Pitch-Catch Inspection System Applied in the Single-Sided Mode

Acoustic emission (AE) methods involve monitoring acoustic emissions associated with the energy released as the structure undergoes inelastic stress relief. These methods are sometimes referred to as passive to contrast them with the active techniques that use an external excitation. These methods have been the subject of significant research and sensors for collecting emissions are readily available. The main challenge in implementing AE is selecting appropriate locations for monitoring a particular structure and establishing criteria for risk-based corrective action. Establishing these criteria can be difficult because of the complex nature of acoustic propagation within large complex structures, such as the Hanford tank domes. Examples of acoustic emission sources are crack propagation, failure of reinforcing members, or fretting. Without reliable models to relate these emissions to individual components or the overall reliability of the structure, it is difficult to establish fitness thresholds. Because of the difficulties in identifying individual source terms, most $\mathrm{AE}$ methods require the development of a strategy monitoring emissions relative to baseline reference data to track structural degradation (Spanner 1974). 
Guided wave methods are based on the unique wave propagation modes that are physically allowed within structures (Rose 1999). The appeal of these methods is that they have the potential for long-range inspections (up to many tens of meters) and to interrogate regions of a structure that are not readily accessible. These modes arise directly from the material properties and the boundary conditions of the structure. Guided wave methods target, or tune, excitations to specific long-range modes supported by the structure or its components. Perturbations to the anticipated propagation can be used, in combination with advanced acoustic propagation models, to deduce changes to the "as-fabricated" structure. While rather simple structures such as plates and cylinders can be handled using closed-form analytical solutions, the complexities of wave propagations in real structures, composites, and structures that have been damaged require advanced computational tools. Instrumentation for the application of guided waves for metallic pipes and vessel walls is available. In most cases specific methods must be developed based on anticipated defects (e.g., wall thinning or cracks) in conjunction with some level of structural simulation.

The applications for concrete have been for bulk characterization and the characterization of layers and layer interfaces. For instance Poisson's ratio and the Young's modulus can be deduced by monitoring Lamb wave propagation and Rayleigh surface waves can be used to identify the location of layers (Wardany et al. 2007). Research is being conducted to use guided wave modes to assess the condition of rebar and tendon components. The main challenge with these applications is the parasitic energy loss associated with the intimate contact of these components with the concrete. The choice of frequency can be used to mitigate these losses (Pavlakovic et al. 1999; Rizzo and Lansa di Scalea 2004). Although progress is being made in the area of guided waves, as applied to concrete, this requires a detailed analysis of the associated wave mechanics for data interpretation. Generic commercial instruments are not yet available.

\subsection{Thermographic NDE}

Thermographic NDE (sometimes referred to as thermal NDE or TNDE) techniques rely on quantifying thermal transients at the surface of a structure of interest. These transients are governed by the heat transfer, primarily thermal diffusion, within the structure and between the structure and its environment. TNDE is typically distinguished from the general field of infrared imaging in that it relies on the analysis of heat transfer to extract material and geometrical information about structures. Only a small fraction, less than 5 percent, of thermographic applications fall into this category with the vast majority of the use of infrared imaging being of the "point and shoot" variety. This technique is very sensitive to laminar discontinuities that are often difficult for radiography to identify. It also works well with non-metallic materials and is popular with composites. The source of the excitation may be internal, as in the case of the exotherms associated with curing concrete, or external. In fact, the generation of the thermal gradients may even be achieved by localized cooling. Optimum excitation is selected to elucidate the structural feature of interest. These span the range of step heating, use of the diurnal cycle, alternating temperature cycles (heating and cooling at specific frequencies), and pulse heating.

Figure 10 illustrates a system that uses a step-heating excitation to rapidly inspect metallic tank walls and sections of a boiler. From a data analysis perspective there are several analogies to acoustic NDE. In both cases the measurement involves the excitation and monitoring of accessible surfaces (a time-varying boundary condition) with the relative impedance at internal boundaries controlling the energy propagation (wave mechanics for acoustics and diffusion for heat transfer). Knowledge of material properties 
(thermal conductivity, density, and specific heat), distribution of materials, and geometry are all important to assessing the appropriateness of this technique and selecting an optimal excitation source and data analysis methodology (Watkins 1998; Watkins and Hinders 1998; Watkins 1999; Watkins and Hinders 1999).

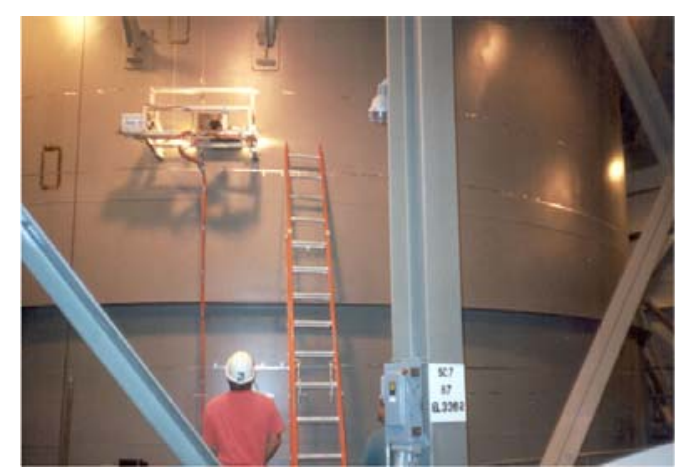

(a)

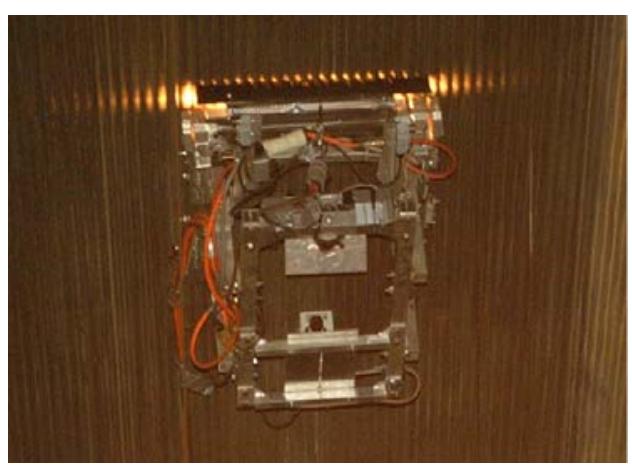

(b)

Figure 10. Example of Thermal NDE System for the Inspection of (a) Tank Wall and (b) Boiler Section. Images courtesy of Therm-Tech Services, Inc.

The use of thermographic techniques has gained wide use in the last decade. There are several reasons for this surge in use. The first is that the most expensive component of these inspection systems, the infrared cameras, continues to decrease in price and increase in sensitivity. Secondly, enhancements in computational speeds allow for the in-field extraction of structural information for inspectors. Standardization is still evolving.

The use of thermography for relatively gross structural defects is straightforward and often requires minimal analysis. In this case, gross voids in the as-fabricated condition are easily detected and often quantified. Figure 11 illustrates the use of thermography to locate gross structural voids in a concrete wall. In this case the wall contained 50 percent voids. When considering the use of this technology for the quantification of more subtle damage, it is advisable to conduct a careful method analysis to assess the anticipated sensitivity. Thermal NDE has been successfully applied in the detection of metal wall losses of less than 5 percent. While the detailed heterogeneity and heat transfer properties determine the limits of detection, a good rule of thumb is that it is difficult to size voids that are deeper than approximately two times the lateral extent (i.e., length of the void parallel to the surface). Detection at greater depths is sometimes possible.

The most effective use of thermography for more subtle defects requires careful consideration of the defect or degradation of interest, selection of the excitation source, and analytical methods. When designed carefully, thermographic methods are highly sensitive to concrete conditions that impact heat transfer. Examples are moisture content, relative ratio of cement to aggregate, and porosity. The major instrument components are readily available. It is anticipated that significant tank dome rebar corrosion, at the top mat, would have to exist for a thermographic technique to be useful. It does however represent a technology with available off-the-shelf instrumentation for which methods could be developed to inspect for major voids and/or porosity. 


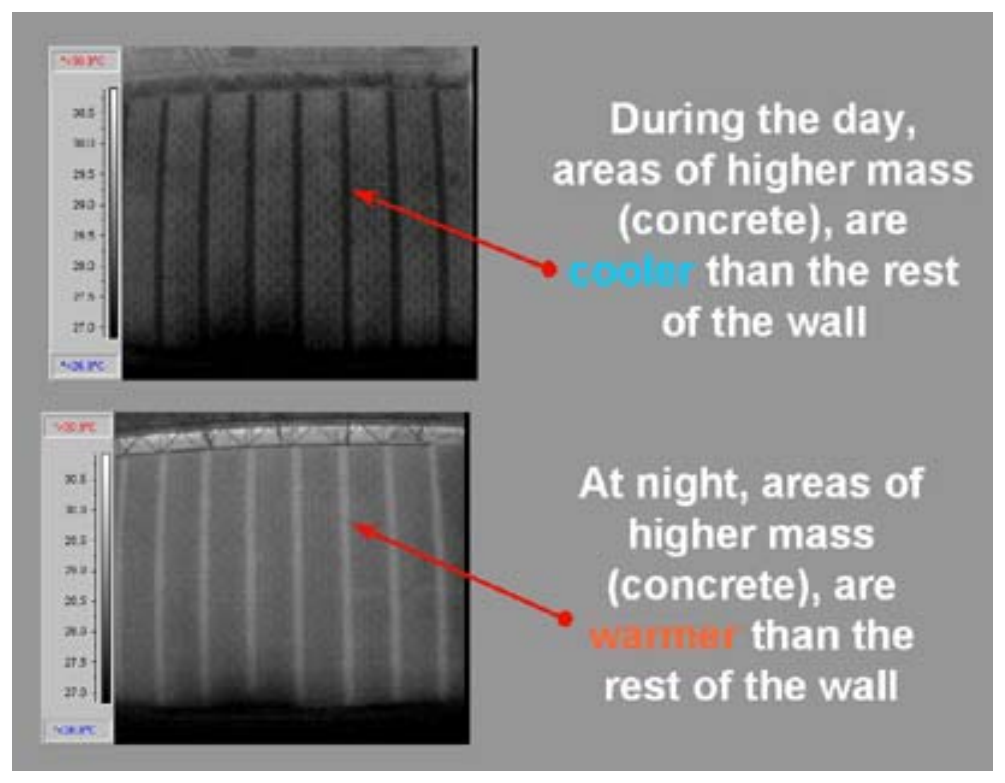

Figure 11. Thermographic Inspection of a Concrete Wall Using Diurnal Cycle to Detect Large Voids. Images courtesy of Stockton Infrared Thermographic Services, Inc.

\subsection{Electrochemical Methods}

Electromagnetic techniques encompass all methods that rely on the interaction of electromagnetic fields with the structural components. It is common to differentiate between those methods that are designed to measure the electrochemical activity associated with reinforcement corrosion via circuit analysis and those that are not explicitly based on a circuit model. While these techniques are not strictly nondestructive they are minimally invasive and warrant discussion because they are complementary to many of the nondestructive methods and are common in the literature and marketplace.

There are several localized measurement techniques that are sensitive to the electrochemical processes associated with corrosion. These are intended to provide indications of the likelihood that corrosion is occurring and the rate of corrosion. ASTM C876 references a half-cell potential measurement designed to indicate the likelihood of active corrosion. Figure 12 is an illustration of a commercial half-cell instrument. This measurement takes advantage of the potential (voltage), created when an electrochemical reaction occurs between steel rebar and concrete. This measurement provides a gross qualitative indication of the likelihood that corrosion is taking place. An electrical circuit is established by making a direct electrical connection with rebar, the "working electrode." The opposite pole of the "virtual battery" consists of a reference cell that couples, through the concrete, to a downrange segment of the same piece of rebar. The voltage potential across this segment, which is in series with the rebar, provides a qualitative indicator of the severity of the corrosion. The hand-held half-cell unit can be scanned across the surface to generate multiple readings. While the correlation of half-cell results is mechanistically and statistically applicable, the quantitative value is generally considered to be weak and applicable only for rebar that is relatively close to the surface (several inches). While it is valuable for discriminating very low corrosion levels from very high corrosion, the accuracy for 
quantifying the level of corrosion is poor. The data derived from this measurement depends not only on the condition of the "as-is" reinforcement, but also on the moisture content of the concrete and the location of the reinforcement. Half-cell measurements are often combined with an induction "covermeter" method to reduce variations due to the distance between the rebar and the half-cell. The half-cell technique is more valuable when referenced with an "as-built” baseline reading as part of a routine monitoring program. Recent research has investigated variations on the half-cell method that eliminate the need to make direct electrical contact to the reinforcing members.

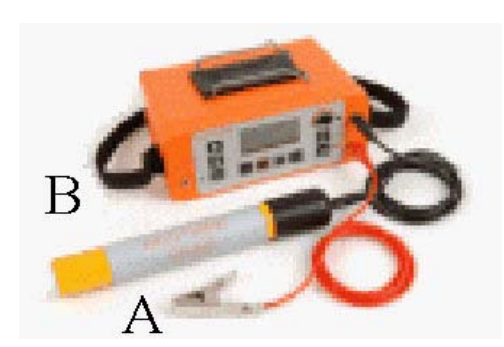

Figure 12. Half-Cell Instrumentation. (A) Electrical rebar contact, (B) reference half-cell which inductively couples to the rebar through the concrete. Image courtesy of Elcometer Instruments Ltd.

There are several methods that provide information on the rate of corrosion. These methods rely on the ion transport current associated with active corrosion. The mobility of ions within the concrete matrix has a significant influence over the corrosion rate of rebar. Thus a measurement of the electrical conductivity of the concrete, independent of the rebar, provides an indicator of the ease with which ion exchange takes place. This measurement is made using a commercial four-point probe that eliminates the contact resistance at the probe-concrete interface. Other methods rely on perturbing the corrosion current and assessing the resistance to polarization.

The linear polarization method, developed approximately 20 years ago, is also available commercially. This method uses a dc bias current, applied directly to the rebar, to acquire a voltage signal that is proportional to the corrosion current density. The instrument's pick-up electrode is inductive and this method assumes the volume of steel being subjected to the polarization filed is known and constant. Most commercial units now come with ring electrodes to localize the field and helps ensure that the observed resistance is confined to the reinforcing member that is physically connected to the circuit. Like the half-cell method this approach is only valid for shallow depths (several inches). In addition, there can be wide variations with temperature and moisture.

Other methods involve monitoring induced or spontaneous fluctuations in electrochemical currents. Examples are the use of broad-band excitation sources such as a pulse (galvanostatic pulse method) or sweeping with ac currents of various frequencies (electrochemical impedance spectroscopy). The principle is that the induced transients are fundamentally related to the quasi-steady state corrosion current. Another approach is to embed sensors into the concrete structure and monitor the naturally occurring fluctuations of currents and fields (electromagnetic emissions). This approach is analogous to monitoring acoustic emission for signs of structural degradation. Like acoustic emission, the threshold criteria for taking mitigating actions must be carefully considered before instituting such monitoring 
programs. While these later methods have shown promise, the interpretation of the results is complex and standardization of the methods is still maturing.

The likely value of using the above electrochemical methods to characterize tank dome rebar will be to provide complementary or investigatory information as a follow-up to initial visual inspections of the tank dome concrete. They may also provide a basis for developing a future monitoring program.

\subsection{Electromagnetic NDE}

When discussing the more traditional (relative to those presented in Section 2.3) electromagnetic NDE methods, it is useful to place them in the context of the electromagnetic spectrum (Figure 13). Note that while techniques utilizing radiation such as in the x-ray, visible, infrared bands are fundamentally treated as electromagnetic, in the context of concrete inspection methods that interrogate below the surface "electromagnetic techniques" involve frequencies from DC to around $10 \mathrm{GHz}$. Coupling or penetration is typically achieved through air. Regardless of the detailed coupling, each of these methods involves the excitation and monitoring of electromagnetic wave propagation within the structure. The analytical approaches to describing this interaction depend on the dielectric and resistivity properties and the geometry of the components. The presence of significant corrosion products introduces significant changes in both material properties and geometry.

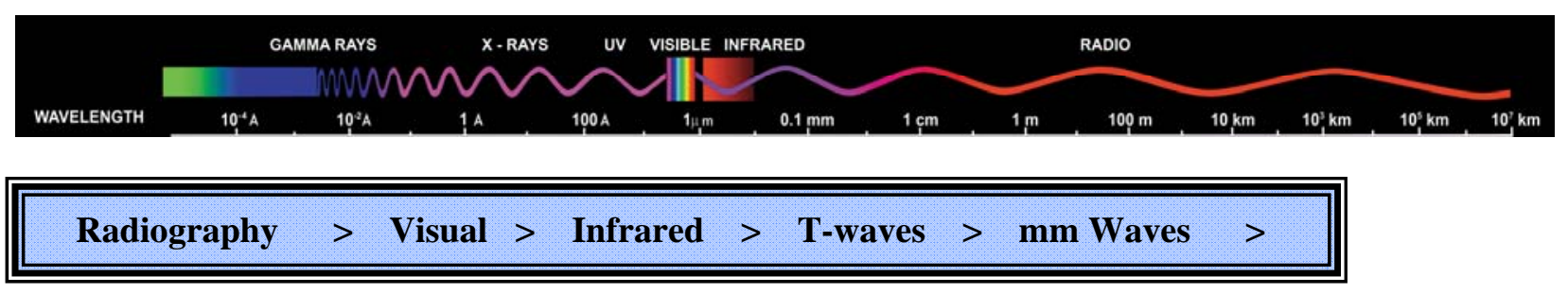

Figure 13. Bands of the Electromagnetic Spectrum

The most widely used stand-off electromagnetic techniques are variations of eddy-current induction. Eddy-current methods rely on the fact that an externally applied alternating magnetic field in proximity to a conductor induces alternating currents in the conductor. The depth and density of these currents depend on the proximity and frequency of the excitation coil, the frequency of the excitation, the electrical resistivity, the magnetic permeability of the conductor, and its size and shape. A variation of this technique uses a magnetic core in conjunction with excitation and sensing coils to enhance coupling to rebar. Both of these techniques are sensitive to the depth (often referred to as the rebar "cover") and the condition of rebar. These techniques are typically used to verify the location of rebar members. Because they are also sensitive to other rebar members within the projected field (these may be in the same plane or deeper layers) care must be taken in interpreting the results as they relate to rebar diameter and corrosion. It is extremely difficult to discern the nature of rebar below the top layer.

Radiography is one of the nondestructive methods of testing concrete for obtaining information about concrete quality and defects within the reinforced concrete structure. Because concrete is relatively dense, a high-energy source is necessary for penetration. Radiography is a reliable method of locating internal voids and steel reinforcement in concrete. Radiographic methods are classified into two types, 
$\mathrm{x}$-ray and gamma ray. Only gamma radiography is applicable to field operations such as the tank dome examination because it is relatively easy to transport the source to the job site and to deploy using a placement tube. Radiation is extremely dangerous, so extra precautionary measures are taken.

Figure 14 shows the kind of resolution that is possible using a high-energy source. The figure shows that locating cables and reinforcement steel is viable through many inches of concrete. In the case of the tank dome, an inner 0.375-in. steel liner as well as approximately 15 in. of concrete would need to be penetrated to get any real indication of the condition of the structure. Deployment would have to be performed using a bent tube arrangement with the source cask located roughly $20 \mathrm{ft}$. from the exposure site. Background radiation could cloud the image but using digital radiography could provide some additional dynamic range. This method could be evaluated on a mock-up providing better insight into its real imaging capability (Shaw et al. 2000).

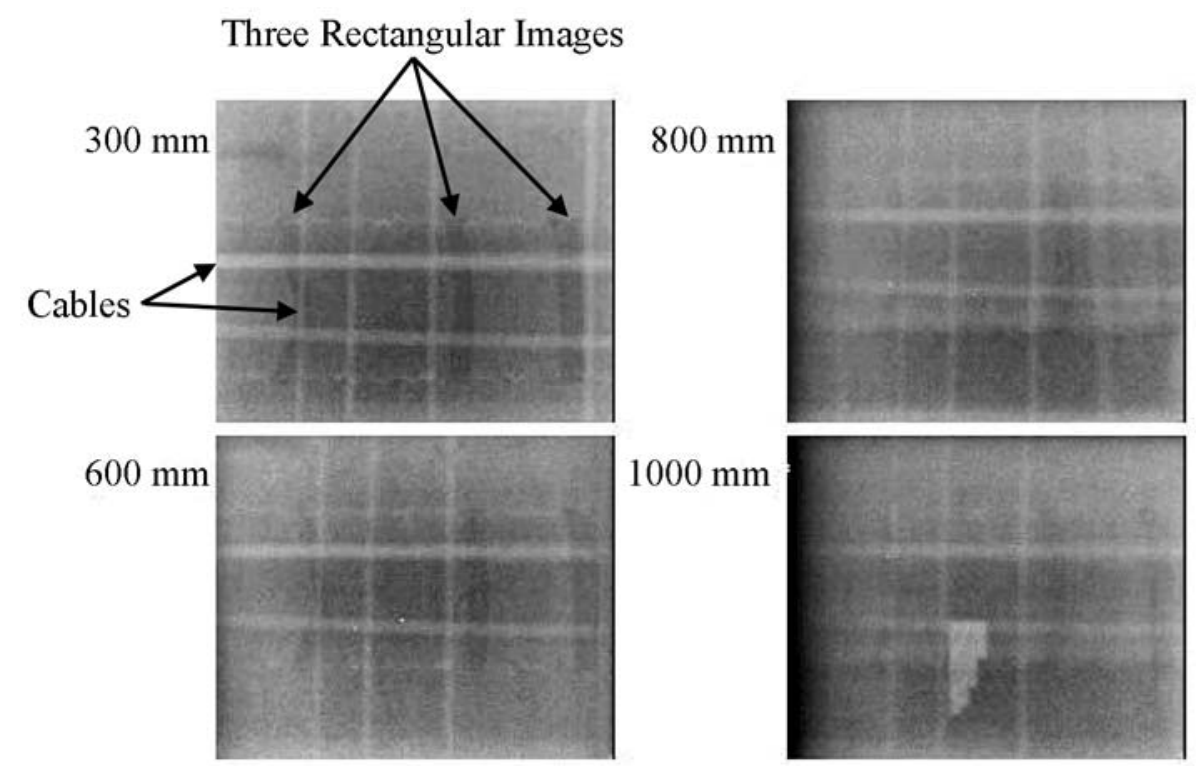

Figure 14. Images of Reinforced Concrete of Different Thickness (300 mm to $1000 \mathrm{~mm}$ ). Cables can be seen in the middle of the images, together with three rectangular voids of 15, 20, and $30 \mathrm{~mm}$ dimension (left to right) (Shaw et al. 2000).

The region of the electromagnetic spectrum referred to as RADAR (from the application of this frequency in Radio Detection and Ranging) has gained significant interest as a tool for inspecting concrete. Most commercial systems for concrete inspection operate in the $1-5 \mathrm{GHz}$ regime. It does not require an ionizing radiation source and is non-contact. Advances in this technology for inspecting concrete structures are being enabled by the reduction in cost of switching components and the computational power associated with signal processing and image reconstruction. Market factors such as the increasing use of composites as structural components (e.g., aerospace) and security applications are driving the maturation of this technology. 
From a wave propagation perspective, RADAR is analogous to SONAR (Sound Navigation and Ranging). While the velocity of propagation of sound varies inversely with the square root of the density of a material, the velocity of propagation of electromagnetic waves varies inversely with the square root of the electric permittivity and the magnetic permeability of a material (for idealized dielectrics, this reduces to the propagation varying inversely with the square root of the dielectric constant). Analogous to acoustics, discontinuities in material properties and material distributions result in impedance mismatches and reflections. The polarization of the reflective wave is determined by the relative change at the dielectric discontinuity. The attenuation of the wave increases as the square root of the product of the frequency, magnetic permeability, and conductivity. The relatively high dielectric constant of water (approximately 80) compared to that of dry concrete (about 5) results in a significant impedance mismatch. While this creates difficulties in locating and characterizing features of interest in moist concrete, in the case of the tank domes, a high sensitivity to water could be advantageous if a significant volume of the concrete structure is relatively dry. This would allow for radar penetration into regions with water intrusion and possibly rebar corrosion. These regions would be detected as areas of high reflectivity. Similarly, the enhanced electrical conductivity associated with the presence of chloride enhances the sensitivity of radar to the conditions that lead to accelerated corrosion.

An important consideration in developing concrete inspection systems is balancing adequate penetration and adequate spatial resolution of the features of interest. While lower frequencies (longer wavelengths) yield higher penetration, diffraction limits require higher frequencies for high spatial resolution. Systems designed for ground penetration often operate at lower frequencies. As with acoustics, sophisticated pulse shaping and the tailoring of spectral content enhance the level of detail that can be obtained (in fact, many of the recent advances in acoustics have come by leveraging pulse-shaping techniques developed in radar).

Commercial radar systems come in a wide variety of packages for different applications. Figure 15 and Figure 16 illustrate two such systems. Off-the-shelf radar instruments require manual scanning. Registration technique along the scan surface influences the spatial accuracy of measurements. The raw data obtained from these scans are typically presented in the time domain. Figure 17 illustrates time domain data from such a concrete scan with a series of rebar reflectors above one another. The $\mathrm{x}$ axis represents distance along which the antenna element was translated and the y axis represents the time delay in the reflected signal. The surface being scanned is located at the top of the chart. Thus, the sequential parabolas created at the top of the chart indicate a series of reflectors near the surface. The partial parabolas near the bottom of the chart indicate reflectors below the first set. Note the partial shadowing of the lower layer by the top layer and the complex patterns created by multiple reflections at the various interfaces. The detailed interpretation of this data is complex and requires certain assumptions about the underlying structure. Independent information regarding material properties and geometry can prove to be very valuable in gleaning additional insights into the condition of the structure. 
Conquest can locate and estimate depth of post tension ables. The results of a 24" $\times$ 96" GPR eurvoy aro ehown. The two dopth elicoe illuetrato how the post tension cable moves progressively deeper in the concrete.
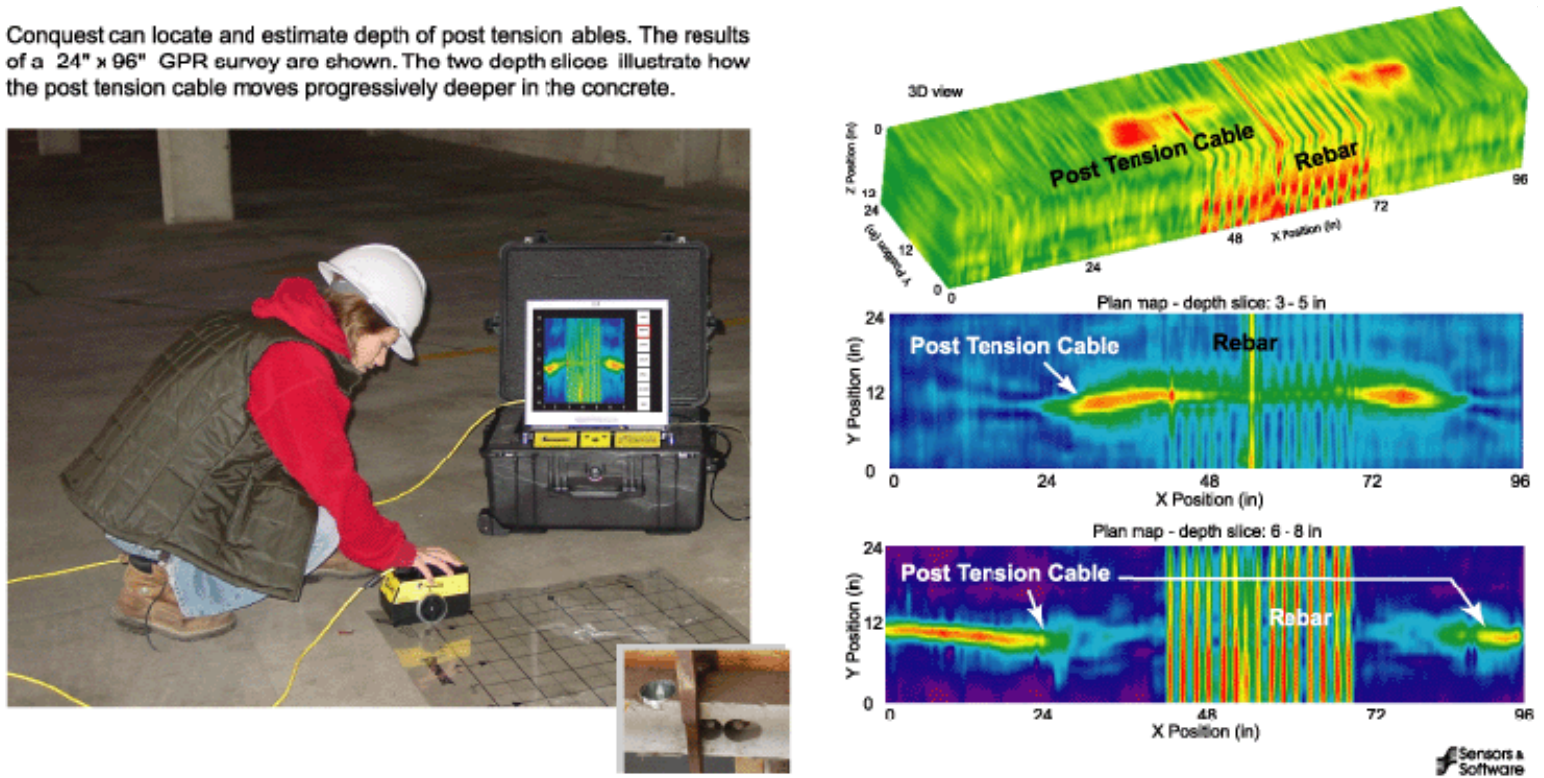

Figure 15. Handheld Radar System from Sensors \& Software Inc. and 3D Rendering of Radar Data (http://www.sensoft.ca)

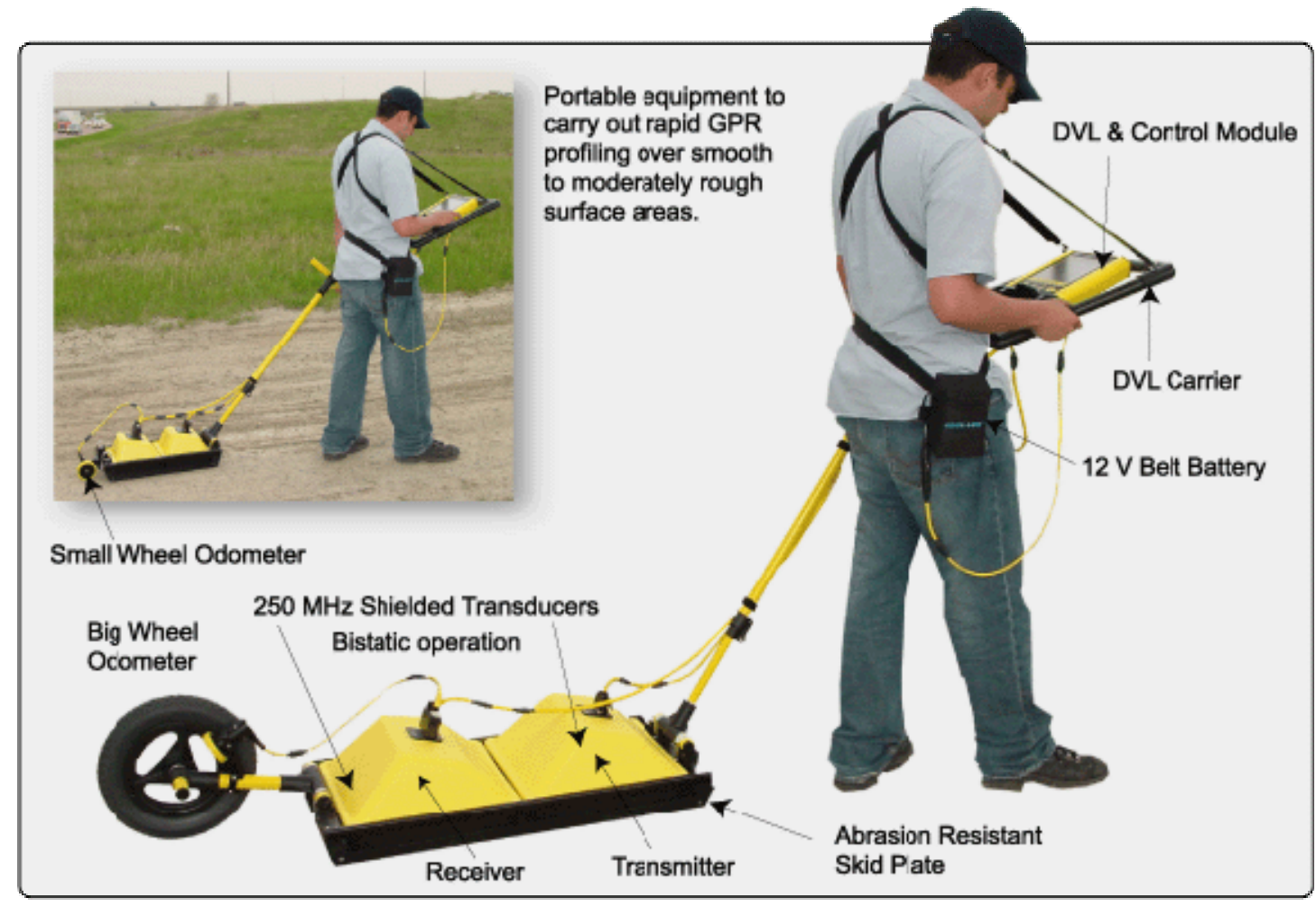

Figure 16. Portable Radar System from Geophysical Survey Systems, Inc. (GSSI) (http://www.structurescan.com/ ) 


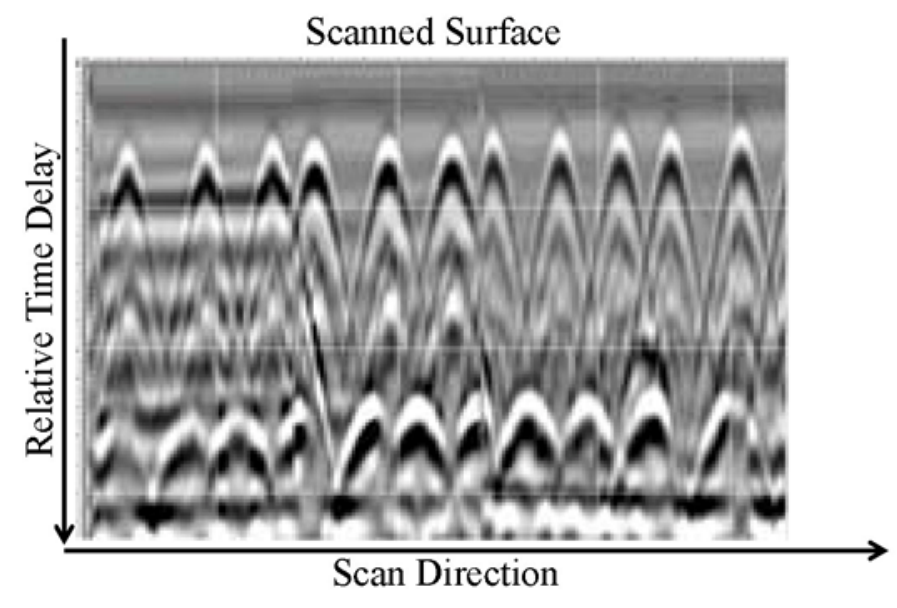

Figure 17. Time-Domain Representation of Radar Reflections from Rebar. The $\mathrm{x}$ axis represents distance along a scan axis. The y axis represents the relative time delay in the reflected signal. The surface being scanned is represented by the top of the chart. Thus, the sequential parabolas created at the top of the chart indicate a series of reflectors near the surface. The partial parabolas near the bottom of the chart indicate reflectors below the first set. Image obtained from http://www.structurescan.com.

Recent market offerings include three-dimensional renderings created by post-processing raw radar data. Figure 18 is an example of rendering in the plan view. Unfortunately the algorithms and underlying assumptions used in these reconstructions are proprietary, and it is not possible to assess the quality and limitations of the analytical methods used to generate the derived structural data. In addition, the data is not provided in formats that are compatible with structural analysis. However, appropriately designed studies, using mock-up concrete sections, would allow for an assessment of the accuracy and limitations of these algorithms as they might be applied to tank domes. PNNL owns a commercial radar unit (GSSI, structurescan) and has staff trained in its operation (Sheen et al. 2001, 2007).

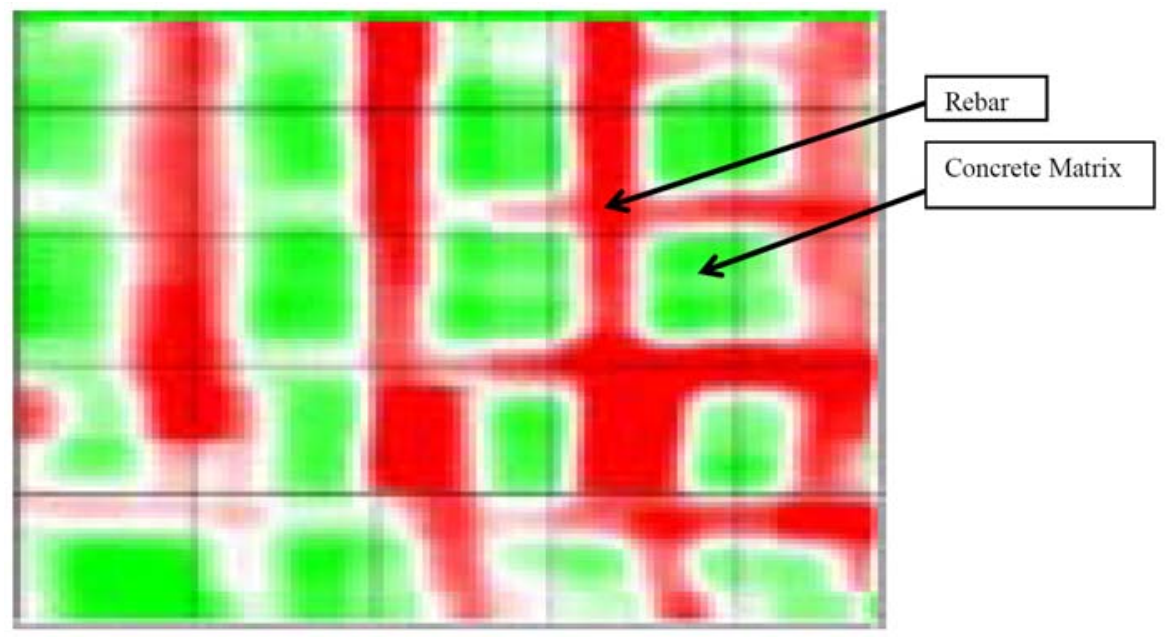

Figure 18. Example of Rendering in Plan View 
RPP-ASMT-37898

\subsection{Description of Relevant Material and Physical Properties}

As described in Section 1, the current operating hypothesis is that the signs of water intrusion, rust, and mineral deposit buildup within the annulus of AY-101 could be associated with a leak path that channeled water between the secondary/primary tank interface and under a flashing strip that was tack welded over the interface. Water intrusion in the area of the concrete construction joint located just above the upper haunch area where the primary and secondary tanks converge could increase the potential of rebar corrosion and subsequent concrete spalling. In a paper presented at the $15^{\text {th }}$ World Conference on $N D T$ in 2000, the authors provided a succinct description of the corrosion problem in reinforcing steel. They ended the article by explaining how complex the real problem is and how it may take a combination of several methods before any definitive conclusions can be made.

"New-built concrete is alkali and reinforcement corrosion is obstructed. Decrease of pore water pH value causes depassivation of metal surface and initiation of corrosion. Penetration of chloride ions from environment in concrete and reaction with atmospheric carbon dioxide are the main source of corrosion. Corrosion products have bigger volume than steel, which causes tensile strains in concrete. If the tensile strains are bigger than tensile strength of concrete, the result is cracking of concrete. Penetration of chlorides and diffusion of carbon dioxide are increased at the places of cracks, which further increases corrosion. Another consequence of crack formation is the development of galvanic cells with anodic and cathodic areas with corrosion at unprotected (anodic) areas. Pitting corrosion and galvanic macrocell formation generate small losses of steel, but create areas with concentrations of strains"

“... determination of reinforcement steel with nondestructive methods is complex and may lead to wrong interpretation of results. To avoid misinterpretation it is recommended to combine several nondestructive testing methods, before making any conclusion about reinforcement steel corrosion" (Bjegovic et al. 2000)).

To investigate this hypothesis it is important to both assess the relevant structural importance of the rebar sections and to determine an approach to inspect for the presence of water, spalling, and/or corrosion.

A load sensitivity analysis ${ }^{(a)}$ was performed in which the cross-section of the rebar was reduced to approximately 50 percent of its "as-built" specification. This work is similar to an analysis performed as part of the TSR Recovery Plan (RPP-ASMT-34090 ${ }^{\mathrm{b}}$ ). Assuming nominal operating loads (addition of seismic loads may give a different conclusion), the demand/capacity ratio was used as a metric of comparison. The following inspection priority was identified:

1) Internal meridional rebar,

2) Circumferential (either internal or external) rebar, and

3) External meridional rebar.

Based on the review of the NDE technologies it is anticipated that the internal meridional rebar will be the most difficult to inspect and the external meridional rebar will be the easier. Figure 19 provides a

(a) Deiber, John E. DST Rebar Inspection Prioritization, 4/2/08 e-mail attachment.

(b) Boomer KD. June 2007. Hanford Double-Shell Tank Thermal and Seismic Project -- Effects of Dome Rebar and Concrete Degradation. RPP-ASMT-34090. CH2M Hill Hanford Group, Inc., June 2007. 
three-dimensional aperture that an inspection technology would be faced with. The most important mat of rebar from a structural point is shown highlighted. With the rebar spaced at approximately 4.5 in. considerable occlusion will occur when examining the internal meridional rebar. Figure 19a shows the top and bottom mats lined up directly over each other. This would probably be the worse case because the bottom mat is almost completely occluded. Figure 19b shows the top mat shifted slightly, which is probably more likely the case in real tank construction and the bottom (internal meridional) rebar is visible.

Considering the fact that corrosion and water intrusion products have been identified in the annulus, it is also reasonable to believe that if water and corrosion are detected in the region of concrete where the external meridional rebar is located there may be corrosion of the internal meridional rebar.

As described in the context of the various inspection technologies, the key bulk material properties are the electromagnetic properties (electrical conductivity, electric permittivity, magnetic permeability), the elastic moduli, and the density. In addition, component size and distribution, especially as it relates to the wavelength involved, are also important. In the case of the tank domes the rather large aggregate is expected to create noticeable scattering that will have to be addressed.

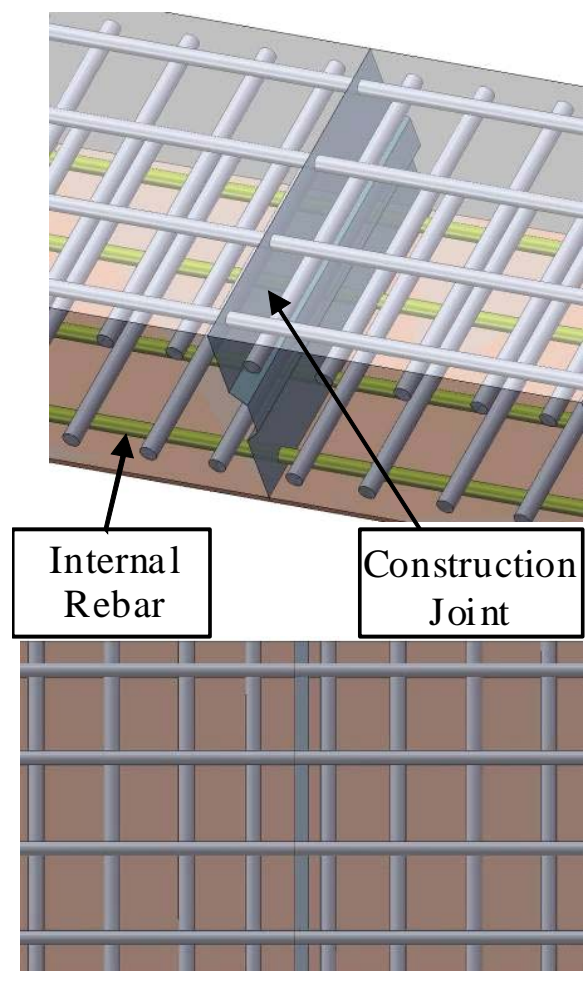

a.
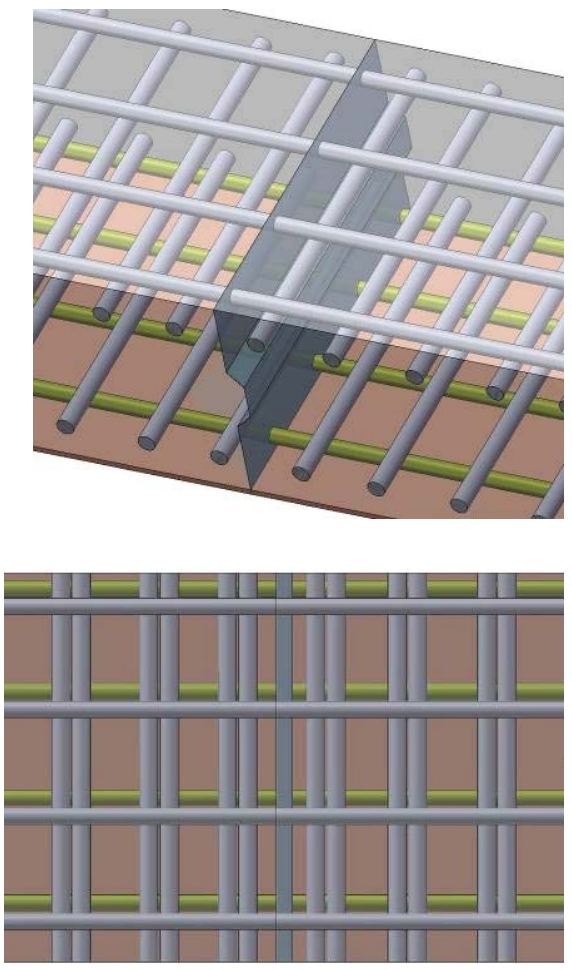

b.

Figure 19. Illustration of the Dimensional Aperture Presented to the Inspection Technology 
RPP-ASMT-37898

\subsection{Technology Matrix}

Table 1 summarizes the results of the technology review by class and recommendations. These recommendations could change if new information is obtained on the state and nature of any identified concrete degradation. A rough order of magnitude (ROM) cost can be provided to evaluate the technology for inspecting the tank dome concrete via slab mock-ups that include an appropriate matrix addressing the key structural features (e.g. rebar thickness loss, spalling etc.). 
Table 1. Technology Matrix

\begin{tabular}{|c|c|c|c|c|}
\hline Technology & Recommendation & $\begin{array}{l}\text { Fundamental Principle of } \\
\text { Operation }\end{array}$ & Technical Maturity & $\begin{array}{c}\text { ROM (\$) } \\
\text { for } \\
\text { Evaluation }\end{array}$ \\
\hline \multicolumn{5}{|c|}{ Electromagnetic } \\
\hline \multicolumn{5}{|c|}{$\begin{array}{l}\text { Uses the interaction of electromagnetic wave propagation with structural discontinuities in material electromagnetic properties. Impedance mismatches } \\
\text { created by changes in electric permittivity, magnetic permeability, and conductivity result in reflected waves and changes in polarity. }\end{array}$} \\
\hline Radar & $\begin{array}{l}\text { The recommendation is to } \\
\text { evaluate this technology } \\
\text { using a small scale } \\
\text { mockup (e.g. } 5 \text {-ft. } x \text {-ft. } x \\
\text { 15-in.) of the tank dome } \\
\text { construction. }\end{array}$ & $\begin{array}{l}\text { Uses antennas to launch and receive } \\
\text { electromagnetic waves that interact } \\
\text { with complex structures. Sensitive to } \\
\text { dielectric and electrically conductive } \\
\text { materials. Can be used to image } \\
\text { concrete structures based on reflective } \\
\text { energy and changes in the polarization } \\
\text { of the returned waves. Typically } \\
\text { frequencies in the } \mathrm{MHz} \text { to GHz } \\
\text { regime. }\end{array}$ & $\begin{array}{l}\text { Less expensive and faster than radiography without } \\
\text { the ionizing radiation source concerns. Does not } \\
\text { provide the spatial resolution of radiography for } \\
\text { rebar. Radar technology is highly sensitive to } \\
\text { water, rebar, and conductive species such as } \\
\text { chloride ions. These materials/features can obscure } \\
\text { structures and features of interest. Off-the-shelf } \\
\text { sensor platforms are available for manual scanning. } \\
\text { PNNL has a structure scan unit and internally } \\
\text { developed prototypes. Radar can be integrated into } \\
\text { custom automated scanners. Data is complex. } \\
\text { Commercial and experimental algorithms require } \\
\text { validation. }\end{array}$ & $<\$ 135 \mathrm{~K}$ \\
\hline \multicolumn{5}{|l|}{ Radiography } \\
\hline Radiography & $\begin{array}{l}\text { Not Recommended at this } \\
\text { time. However, evaluation } \\
\text { and comparison of the } \\
\text { basic technology may be } \\
\text { relatively simple and } \\
\text { relatively inexpensive } \\
\text { using the small scale } \\
\text { mockup recommended in } \\
\text { the radar evaluation. }\end{array}$ & $\begin{array}{l}\text { Attenuation of high-frequency, high- } \\
\text { energy is highly dependent on the } \\
\text { atomic number }\end{array}$ & $\begin{array}{l}\text { Radiography is a proven technology for imaging } \\
\text { complex structures. Radiation sources, detectors, } \\
\text { and image algorithms are available. A tank dome } \\
\text { inspection system would require a powerful source, } \\
\text { long exposure times, and complex custom scanning } \\
\text { system. }\end{array}$ & $<\$ 75 \mathrm{~K}$ \\
\hline
\end{tabular}




\begin{tabular}{|c|c|c|c|c|}
\hline Technology & Recommendation & $\begin{array}{c}\text { Fundamental Principle of } \\
\text { Operation } \\
\end{array}$ & Technical Maturity & $\begin{array}{l}\text { ROM (\$) } \\
\text { for } \\
\text { Evaluation } \\
\end{array}$ \\
\hline \multicolumn{5}{|l|}{ Thermography } \\
\hline Thermography & $\begin{array}{l}\text { Not Recommended at this } \\
\text { time. However, evaluation } \\
\text { and comparison of the } \\
\text { basic technology, using } \\
\text { leased equipment, may be } \\
\text { relatively simple and } \\
\text { relatively inexpensive } \\
\text { using the small scale } \\
\text { mockup recommended in } \\
\text { the radar evaluation. }\end{array}$ & $\begin{array}{l}\text { Measures transients in thermal } \\
\text { gradients using real-time infrared } \\
\text { imaging. The observed transients at } \\
\text { selected boundaries (single sided } \\
\text { access is viable) yield information on } \\
\text { the internal heat transfer which is } \\
\text { governed by subsurface structures and } \\
\text { material thermal properties. }\end{array}$ & $\begin{array}{l}\text { Commercial systems and sub-systems are available. } \\
\text { Highly sensitive to planar discontinuities. } \\
\text { Relatively fast and highly sensitive to moisture } \\
\text { content. Like radar, the available systems would } \\
\text { need to be adapted for deployment at the tank farm. } \\
\text { Selection of the inspection modality (excitation } \\
\text { source, data collection, and interpretation) is } \\
\text { significantly enhanced by some level of thermal } \\
\text { simulation of the structure. }\end{array}$ & $<\$ 50 \mathrm{~K}$ \\
\hline \multicolumn{5}{|c|}{$\begin{array}{l}\text { Electrochemical } \\
\text { This class of mea }\end{array}$} \\
\hline Half-cell & $\begin{array}{l}\text { Not Recommended at this } \\
\text { time }\end{array}$ & $\begin{array}{l}\text { Measures electrical potential created } \\
\text { when rebar is attacked by corrosion }\end{array}$ & $\begin{array}{l}\text { Commercial instruments are available to provide a } \\
\text { qualitative indicator of the presence of corrosion. } \\
\text { Measurements are straight forward and much more } \\
\text { useful when compared to baseline "as-constructed" } \\
\text { data. Requires direct electrical connection with } \\
\text { rebar to establish conduction path. }\end{array}$ & $\$ 25-50 \mathrm{~K}$ \\
\hline $\begin{array}{l}\text { Linear } \\
\text { polarization }\end{array}$ & $\begin{array}{l}\text { Not Recommended at this } \\
\text { time }\end{array}$ & $\begin{array}{l}\text { Uses a dc bias current, applied directly } \\
\text { to the rebar, to acquire a voltage signal } \\
\text { that is proportional to the corrosion } \\
\text { current density }\end{array}$ & $\begin{array}{l}\text { Commercial instruments are available to provide a } \\
\text { qualitative indicator of the rate of corrosion. } \\
\text { Measurements are straight forward and much more } \\
\text { useful when compared to baseline "as-constructed" } \\
\text { data. Requires direct electrical connection with } \\
\text { rebar to establish conduction path. } \\
\end{array}$ & $\$ 25-50 \mathrm{~K}$ \\
\hline $\begin{array}{l}\text { Advanced } \\
\text { polarization } \\
\text { methods }\end{array}$ & $\begin{array}{l}\text { Not Recommended at this } \\
\text { time }\end{array}$ & $\begin{array}{l}\text { These methods use ac or pulsed } \\
\text { excitations to induce current transients } \\
\text { that are indicative of the corrosion } \\
\text { current density. }\end{array}$ & $\begin{array}{l}\text { Some commercial instruments are available and } \\
\text { further research is underway. The data can be } \\
\text { analyzed to provide a qualitative indicator of the } \\
\text { rate of corrosion. }\end{array}$ & $\$ 50-100 \mathrm{~K}$ \\
\hline
\end{tabular}




\begin{tabular}{|c|c|c|c|c|}
\hline Technology & Recommendation & $\begin{array}{l}\text { Fundamental Principle of } \\
\text { Operation }\end{array}$ & Technical Maturity & $\begin{array}{l}\text { ROM (\$) } \\
\text { for } \\
\text { Evaluation }\end{array}$ \\
\hline \multicolumn{5}{|c|}{ Electromagnetic } \\
\hline \multicolumn{5}{|c|}{$\begin{array}{l}\text { Uses the interaction of electromagnetic wave propagation with structural discontinuities in material electromagnetic properties. Impedance mismatches } \\
\text { created by changes in electric permittivity, magnetic permeability, and conductivity result in reflected waves and changes in polarity. }\end{array}$} \\
\hline $\begin{array}{l}\text { Four point } \\
\text { electrical } \\
\text { resistivity }\end{array}$ & $\begin{array}{l}\text { May be valuable after } \\
\text { initial visual inspection or } \\
\text { to corroborate other } \\
\text { techniques }\end{array}$ & $\begin{array}{l}\text { Uses four surface probes and a bridge } \\
\text { circuit to determine the electrical } \\
\text { resistivity of the concrete. Higher } \\
\text { conductivity is associated with a } \\
\text { higher potential for corrosion. }\end{array}$ & $\begin{array}{l}\text { Off-the-shelf instruments are readily available and } \\
\text { instruments are easy to operate. Measurement } \\
\text { requires access to the surface of the concrete. }\end{array}$ & $\$ 25-50 \mathrm{~K}$ \\
\hline Eddy current & $\begin{array}{l}\text { Not Recommended at this } \\
\text { time }\end{array}$ & $\begin{array}{l}\text { Uses inductive coils or solid state } \\
\text { sensors to inductively couple to } \\
\text { conductive materials through } \\
\text { dielectric materials. Is sensitive to } \\
\text { stand-off from conductors and the } \\
\text { resistivity of the conductor. Typically } \\
\text { involves lower frequencies }(\mathrm{kHz} \text { to } \\
\mathrm{MHz} \text { ) than radar (MHz to } \mathrm{GHz} \text { ). }\end{array}$ & $\begin{array}{l}\text { Off-the-shelf sensors and instruments are available. } \\
\text { Has been proven to be valuable in detecting the } \\
\text { presence of rebar in concrete. Application to tank } \\
\text { domes would require method development and } \\
\text { engineering. Automated scanning can be } \\
\text { accommodated. }\end{array}$ & $\$ 50-75 \mathrm{~K}$ \\
\hline \multicolumn{5}{|c|}{$\begin{array}{l}\text { Acoustic } \\
\text { Uses the interaction of elastic wave propagation with structural discontinuities in material density and moduli. The impedance mismatches } \\
\text { arising from these discontinuities result in reflected waves, mode conversions, and changes in polarity. }\end{array}$} \\
\hline $\begin{array}{l}\text { Through } \\
\text { Transmission }\end{array}$ & $\begin{array}{l}\text { Not Recommended at this } \\
\text { time }\end{array}$ & $\begin{array}{l}\text { Uses time of flight and attenuation of } \\
\text { elastic waves to deduce thickness, or } \\
\text { bulk density, or bulk modules }\end{array}$ & $\begin{array}{l}\text { Equipment is readily available. Requires access to } \\
\text { two sides. Analysis is complicated by } \\
\text { heterogeneous structures such as the tanks dome. } \\
\text { Equipment is relatively inexpensive. }\end{array}$ & $<\$ 50 \mathrm{~K}$ \\
\hline Phased Array & $\begin{array}{l}\text { Not Recommended at this } \\
\text { time }\end{array}$ & $\begin{array}{l}\text { Uses imaging similar to medical } \\
\text { ultrasound }\end{array}$ & $\begin{array}{l}\text { This technology is not typically used for concrete } \\
\text { because of the high levels of scattering that result } \\
\text { from the aggregate. Equipment is readily available } \\
\text { yet customized; low frequency adaptations would } \\
\text { be required. Only single-sided access is required. } \\
\text { PNNL has laboratory systems and has adopted this } \\
\text { technology for the inspection of large grain metals } \\
\text { that create scattering problems. Consideration of } \\
\text { this technology would require an R\&D investment. }\end{array}$ & $<\$ 200 \mathrm{~K}$ \\
\hline
\end{tabular}




\begin{tabular}{|c|c|c|c|c|}
\hline Technology & Recommendation & $\begin{array}{c}\text { Fundamental Principle of } \\
\text { Operation }\end{array}$ & Technical Maturity & $\begin{array}{l}\text { ROM (\$) } \\
\text { for } \\
\text { Evaluation }\end{array}$ \\
\hline $\begin{array}{l}\text { Impact-echo } \\
\text { method }\end{array}$ & $\begin{array}{l}\text { Not Recommended at this } \\
\text { time }\end{array}$ & $\begin{array}{l}\text { Mechanical impact source excites an } \\
\text { elastic wave that propagates into the } \\
\text { surface and reflects back to same-side } \\
\text { transducer }\end{array}$ & $\begin{array}{l}\text { Equipment is readily available. Single-sided access } \\
\text { required. Results are qualitative with respect to } \\
\text { structural integrity and most valuable in the context } \\
\text { of "as-constructed" baseline data. }\end{array}$ & $\$ 25-50 \mathrm{~K}$ \\
\hline $\begin{array}{l}\text { Impulse } \\
\text { response }\end{array}$ & $\begin{array}{l}\text { Not Recommended at this } \\
\text { time }\end{array}$ & $\begin{array}{l}\text { Mechanical impact source excites } \\
\text { "broad band" elastic waves that } \\
\text { propagates into the surface and } \\
\text { reflects back to same-side transducer. } \\
\text { The spectral content of the reflected } \\
\text { waves yield information about } \\
\text { distribution of the material properties } \\
\text { below the surface. }\end{array}$ & $\begin{array}{l}\text { Equipment is readily available and data collection is } \\
\text { straight forward. One sided access required. The } \\
\text { significance of the spectral content is best used in } \\
\text { the context of "as-constructed" baseline data or a } \\
\text { detailed structural analysis and simulations to } \\
\text { interpret the spectral content as it relates to } \\
\text { degradation. }\end{array}$ & $\$ 50-100 \mathrm{~K}$ \\
\hline Guided waves & $\begin{array}{l}\text { Not Recommended at this } \\
\text { time }\end{array}$ & $\begin{array}{l}\text { Guided wave methods target, or tune, } \\
\text { excitation to specific long-range } \\
\text { modes supported by the structure or its } \\
\text { components. Perturbations to the } \\
\text { anticipated propagation can be used, } \\
\text { in combination with advanced } \\
\text { acoustic propagation models, to } \\
\text { deduce structural and/or material } \\
\text { changes. }\end{array}$ & $\begin{array}{l}\text { At the present time application to concrete } \\
\text { structures is limited in the R\&D phase. } \\
\text { Instrumentation for the application of guided waves } \\
\text { for metallic pipes and vessel walls are available. In } \\
\text { most cases specific methods must be developed } \\
\text { based on anticipated defects (e.g., wall thinning or } \\
\text { cracks) in conjunction with some level of structural } \\
\text { simulation to identify appropriate modes and } \\
\text { interpret signal data. }\end{array}$ & $<\$ 200 \mathrm{~K}$ \\
\hline $\begin{array}{l}\text { Acoustic } \\
\text { emission (AE) }\end{array}$ & $\begin{array}{l}\text { Not Recommended at this } \\
\text { time }\end{array}$ & $\begin{array}{l}\text { AE methods involve the monitoring of } \\
\text { acoustic energy released as the } \\
\text { structure undergoes inelastic release of } \\
\text { stresses. Examples of acoustic } \\
\text { emission sources are crack } \\
\text { propagation, failure of reinforcing } \\
\text { members, or fretting. The associated } \\
\text { methods have been the subject of } \\
\text { significant research and sensors for } \\
\text { collecting emissions are readily } \\
\text { available. }\end{array}$ & $\begin{array}{l}\text { Off-the-shelf sensors and instruments for collecting } \\
\text { emission data are readily available. AE data is } \\
\text { notoriously difficult to interpret and most R\&D } \\
\text { efforts focus on developing valid methodologies } \\
\text { that relate AE signals to structural health. }\end{array}$ & $\begin{array}{c}\text { Not } \\
\text { estimated }\end{array}$ \\
\hline
\end{tabular}



RPP-ASMT-37898

\subsection{Conclusions and Recommendations}

The hypothesis that water intrusion may contribute to potential rebar corrosion of the tank domes provided the primary guidance in reviewing and evaluating available NDE technologies. Of primary concern is the need to employ technologies that provide the best opportunity for visualizing the rebar and providing quantitative data that can be integrated into structural analysis efforts to better understand and quantify the structural capacity of the domes.

Several techniques (e.g., electrochemical) may ultimately provide useful and corroborative information. The decision to make such measurements should probably be made based on the outcome of visual and internal imaging inspections. In addition, these and other commercially available techniques (e.g., impulse response) that either provide spot measurements or are qualitative and rely heavily on "asfabricated" baseline data as a reference (it is our understanding such data is not available) were not recommended.

The conclusion is that an imaging system capable of locating and quantifying the distribution and conditions of the cement, aggregate, and rebar will provide the most valuable baseline upon which to build a case for the health of the structure. If successful, such a system would fulfill the need to incorporate valuable data into current structural load capacity analysis. In the short term, it is recommended that appropriate structural mock-ups be fabricated. These mock-ups should be specified based on the existing construction drawings and photographic evidence of the construction joint area of the tank dome. Data collected from the mock-up will allow for an assessment of the dependence of measurement capability on access hole size. In considering the relative cost, technical maturity, and fundamental sensitivity to the degradation mechanisms of water intrusion and corrosion, PNNL recommends prioritizing the quantitative evaluation and development of an inspection system based on radar imaging technology. Assuming water intrusion is worst at the top layer of rebar, radar should be sensitive at this depth and may be sensitive to concrete cracks with intrusion of water. It may also be feasible and economically reasonable to evaluate thermographic and radiographic techniques using the mock-ups. A methodology to convert radar data file formats compatible with structural analysis programs should be pursued to assess the implications of any findings.

\subsection{Literature Search}

A literature search was conducted for Concrete Nondestructive Evaluation Methods. The following databases were included: Leona, Hanford Technical Library Catalog; WorldCat; Engineering Village 2 Databases; Cambridge Scientific Abstracts; Science Research Connection; ProQuest; and Nexis.com. The search results provided a listing of over 200 documents. A copy of this literature search will be provided upon request. 


\subsection{References}

ACI Committee 228. (2003). “ACI Committee 228 Home, Nondestructive Testing of Concrete.” Available from

http://www.concrete.org/COMMITTEES/committeehome.asp?committee_code=0000228-00.

Bjegovic D, D Mikulic and D Sekulic. 2000. "Non-destructive corrosion rate monitoring for reinforced concrete structures.” In 15th World Conference on Nondestructive Testing, Octrober 15-21, 2000, Roma, Italy.

Pavlakovic B, MJS Lowe and P Cawley. 1999. “The inspection of tendons in post-tensioned concrete using guided ultrasonic waves.” Insight - Non-Destructive Testing and Condition Monitoring 41:446-448 $\& 452$.

Rizzo P and F Lansa di Scalea. 2004. "Load Measurement and Health Monitoring in Cable Stays via Guided Wave Magnetostrictive Ultrasonics.” Mater Eval 62(10):1057-1065.

Rose JL. 1999. Ultrasonic Waves in Solid Media. Cambridge University Press, Cambridge, New York.

Shaw P, TK Pedersen and R Serluppens. 2000. "High Energy Radiography combined with the Agfa Strukturix DPS-imaging system and comparison with other NDE-methods for inspection of thick reinforced concrete structures.” In 2nd International Conference on NDE in Relation to Structural Integrity for Nuclear and Pressurized Components, 5(08), New Orleans, Lousianna. NDT.net. http://www.ndt.net/article/v05n08/shaw/shaw.htm.

Sheen DM, DL McMakin and TE Hall. 2001. “Three-dimensional millimeter-wave imaging for concealed weapon detection.” Microwave Theory and Techniques, IEEE Transactions on 49(9):15811592.

Sheen DM, DL McMakin and TE Hall. 2007. "Near Field Imaging at Microwave and Millimeter Wave Frequencies.” In Microwave Symposium, 2007 IEEE/MTT-S International, pp. 1693-1696.

Spanner JC. 1974. Acoustic Emission: Techniques and Applications. Intex Pub. Co., Evanston, Illinois.

Stewart CW, SH Bush, CH Delegard, MR Elmore, AB Johnson, AF Pardini, GJ Posakony, FA Simonen, MT Terry and PE Zapp. 2003. Independent Review of Tank 241-AY-101 Fitness for Service. PNNL14176. Pacific Northwest National Laboratory, Richland, Washington.

Wardany RA, G Ballivy, J-L Gallias, K Saleh and J Rhazi. 2007. “Assessment of Concrete Slab Quality and Layering by Guided and Surface Wave Testing.” ACI Materials Journal 104(3):268-275.

Watkins ML. 1998. “The Characterization of Rolled Sheet Alloy Using Infrared Microscopy.” In Nondestructive Characterization of Materials VIII. ed: RE Green Jr. Plenum Press, New York. pp. 263268.

Watkins ML. 1999. The Thermographic Nondestructive Evaluation of Iron Aluminide Green Sheet. Ph.D. Thesis, College of William \& Mary, Williamsburg, Virginia.

Watkins ML and MK Hinders. 1998. "The Characterization of Iron Aluminide Green Sheet Thermal Properties.” Mater Sci Eng 258(1-2):266-269. 
RPP-ASMT-37898

Watkins ML and MK Hinders. 1999. "The Thermographic Nondestructive Evaluation of Iron Aluminide Green Sheet.” In Reviews of Progress in Quantitative Nondestructive Evaluation, Vol. 18. eds: DO Thompson and DE Chimenti. Plenum Publishing. 


\section{Distribution}

No. of

\section{Copies}

\section{Hanford Site}

H. S. Berman R2-58

K. D. Boomer H6-19

C. A. Burke R3-26

J. L. Castleberry R3-26

L. A. Domnoski-Rauch S5-25

J. K. Engeman S5-08

M. T. Terry H6-19

$\begin{array}{ll}\text { D. D. Washenfelder R2-58 } & \text { R. }\end{array}$

\section{Pacific Northwest National Laboratory}
A. F. Pardini
K5-26
G. J. Posakony
K5-26
M. L. Watkins
K5-26
Information Release (2) 